UNIVERSIDADE DE SÃO PAULO

FACULDADE DE MEDICINA DE RIBEIRÃO PRETO

PROGRAMA DE PÓS-GRADUAÇÃO INTERUNIDADES EM BIOINFORMÁTICA

JADSON CARLOS DOS SANTOS

ANÁLISE DA TETRAMERIZAÇÃO DA PROTEÍNA CD38 POR MEIO DE DOCKING MOLECULAR

RIBEIRÃO PRETO - SP

2019 


\section{ANÁLISE DA TETRAMERIZAÇÃO DA PROTEÍNA CD38 POR MEIO DE DOCKING MOLECULAR}

Versão Corrigida

Dissertação apresentada ao Programa Interunidades de Pós-graduação em Bioinformática da Universidade de São Paulo como requisito para obtenção do título de Mestre em Ciências.

Área de concentração: Bioinformática

Orientadora: Profa. Dra. Silvana Giuliatti 
Autorizo a reprodução e divulgação total ou parcial deste trabalho, por qualquer meio convencional ou eletrônico, para fins de estudo e pesquisa, desde que citada a fonte.

Dos Santos, Jadson Carlos

Análise da tetramerização da proteína CD38 por meio de docking molecular. Ribeirão Preto, 2019.

64 p. : il. ; $30 \mathrm{~cm}$

Dissertação de Mestrado, apresentada ao Programa Interunidades de Pós-graduação em Bioinformática da Universidade de São Paulo. Área de concentração: Bioinformática.

Orientadora: Giuliatti, Silvana.

1. Proteína CD38. 2. Tetramerização. 3. Docking Molecular. 4. ClusPro. 5. HADDOCK. 
Nome: DOS SANTOS, Jadson Carlos

Título: Análise da tetramerização da proteína CD38 por meio de docking molecular

Dissertação apresentada ao Programa Interunidades de Pós-graduação em Bioinformática da Universidade de São Paulo como requisito para obtenção do título de Mestre em Ciências.

Aprovado em:

Banca examinadora

Prof. Dr.

Instituição:

Julgamento:

Prof. Dr.

Instituição:

Julgamento:

Prof. Dr.

Instituição:

Julgamento: 


\section{AGRADECIMENTOS}

Primeiramente à minha mãe Nailza Paulino dos Santos pela força, trabalho, honra, amor e dedicação durante cada dia de minha vida.

Agradeço à orientação da Profa. Dra. Silvana Giuliatti pela oportunidade e conselhos durante meu período de trabalho no Laboratório de Bioinformática da FMRP.

Agradeço aos companheiros de laboratório, em especial à Elvira pela amizade e companheirismo.

À minha companheira de vida, namorada e melhor amiga Nathalia Reges Pinheiro por me aturar e contribuir para minha felicidade diária.

Agradeço a todos que contribuíram para meu aprendizado, crescimento pessoal e profissional, principalmente os que trouxeram obstáculos, aos que não acreditaram, mentiram e omitiram. Com vocês eu aprendi a ser correto, vencer os obstáculos, acreditar, buscar a verdade e, assim, ser mais forte hoje.

À Universidade de São Paulo pelos auxílios moradia e alimentação que tornaram possível este trabalho.

À Coordenação de Aperfeiçoamento de Pessoal de Nível Superior (CAPES) do Brasil que financiou este trabalho através de bolsa de estudo.

O presente trabalho foi realizado com apoio da Coordenação de Aperfeiçoamento de Pessoal de Nível Superior - Brasil (CAPES) - Código de Financiamento 001. 


\section{RESUMO}

\section{DOS SANTOS, Jadson Carlos. Análise da tetramerização da proteína CD38 por meio de}

docking molecular. 2019. 64f. Dissertação (Mestrado em Bioinformática) - Programa Interunidades de Pós-graduação em Bioinformática, Universidade de São Paulo, Ribeirão Preto, 2019.

A proteína de membrana CD38 (ADP-ribosil ciclase / ADP-ribose cíclico hidrolase 1) pertence a uma família de proteínas evolutivamente conservada que desempenha papel crucial na fisiologia humana. Primeiramente identificada como molécula de superfície de leucócitos, CD38 atualmente é considerada uma proteína multifuncional amplamente expressa dentro e fora do sistema imunológico, tendo função enzimática e como receptor. Entre os produtos de sua ação enzimática estão potentes mobilizadores dos estoques de cálcio intracelular (cADPR e NAADP) envolvidos na regulação da homeostase deste íon em muitos tipos celulares. A proteína CD38 mostra-se um importante marcador para doenças como diabetes, leucemia, mieloma, asma e na patogênese da infecção pelo HIV. O gene da proteína CD38 está localizado na banda p15 do cromossomo 4 (4p15) humano, sendo constituído por 8 exons. Mais de 98\% de cerca de 77 kb do gene da CD38 é representado por sequências intrônicas. A proteína CD38 foi relatada como uma única cadeia de 45 Kda com cadeias de oligossacarídeo ligadas a resíduos de asparagina, desempenhando importante papel na estabilização de sua estrutura. Composta por um pequeno domínio citoplasmático, um domínio transmembrana e um grande domínio extracelular que contém seu sítio catalítico, a CD38 humana já tem sido demonstrada, por peso molecular, existindo na forma dimérica e tetramérica, sendo sugerido que a justaposição transmembranar de dois ou quatro monômeros da molécula possa gerar um canal cataliticamente ativo para a formação seletiva e influxo de seu produto enzimático. Tendo em vista a relevância da proteína CD38 na homeostase celular e a importância da oligomerização em sua diversidade funcional, o presente trabalho teve por objetivo prever a orientação preferencial da tetramerização da CD38 humana com sua cadeia polipeptídica da porção extracelular por meio de docking molecular. Foi utilizado um método de docking não-direcionado (ClusPro) gerando estruturas, tanto diméricas quanto tetraméricas, incompatíveis com a associação na membrana celular. Um método de docking direcionado (HADDOCK 2.2) foi utilizado e, neste, informações experimentais da literatura e cristais da proteína CD38 foram de grande importância no direcionamento. Como resultado, foi demonstrada a importância das regiões de $\alpha$ hélice 1 na formação de dímeros e das $\alpha$ hélices 2, 4, 6 e 9, além da região de alça entre a cadeia $\beta 5$ e $\alpha$ hélice 8 na formação de dímeros e tetrâmeros compatíveis com a associação na membrana e energeticamente possíveis, como classificado pelo método HADDOCK 2.2. As estruturas tetraméricas, criadas pelo docking direcionado com HADDOCK 2.2, formam um bolsão entre os dímeros. Tal região, na proteína inserida na membrana, poderia ser importante para o influxo do produto catalítico da proteína CD38. Esta região de bolsão foi proposta na literatura por meio de dados experimentais e funcionais. Considera-se a importância de estudos, tanto experimentais quanto in silico, que analisem a formação de tetrâmeros e sua estrutura tridimensional, além de experimentos que possam identificar, como por meio de anticorpos conformacionais, os dímeros e tetrâmeros da proteína CD38.

Palavras-chave: Proteína CD38. Tetramerização. Docking Molecular. ClusPro. HADDOCK. 


\begin{abstract}
DOS SANTOS, Jadson Carlos. Analysis of the tetramerization of the CD38 protein by means of molecular docking. 2019. 73f. Dissertação (Mestrado em Bioinformática) Programa Interunidades de Pós-graduação em Bioinformática, Universidade de São Paulo, Ribeirão Preto, 2019.
\end{abstract}

The membrane protein CD38 (ADP-ribosyl cyclase / ADP-ribose cyclase hydrolase 1) belongs to an evolutionarily conserved protein family that plays a crucial role in human physiology. First identified as a leukocyte surface molecule, CD38 is currently considered a multifunctional protein widely expressed inside and outside the immune system, holding an enzymatic and receptor function. Among the products of its enzymatic action are potent mobilizers of intracellular calcium stocks (cADPR and NAADP) involved in regulating the homeostasis of this ion in many cell types. CD38 protein is an important marker for diseases such as diabetes, leukemia, myeloma, asthma and the pathogenesis of HIV infection. The CD38 protein gene is located in the p15 band of the human chromosome 4 (4p15), consisting of 8 exons. More than $98 \%$ of about $77 \mathrm{~kb}$ of the CD38 gene is represented by intronic sequences. CD38 protein has been reported as a single $45 \mathrm{kDa}$ chain with oligosaccharide chains attached to asparagine residues, playing an important role in stabilizing its structure. Compounded by a small cytoplasmic domain, a transmembrane domain and a large extracellular domain containing its catalytic site, human CD38 has already been demonstrated, by molecular weight, existing in the dimeric and tetrameric form, and it is suggested that the transmembrane juxtaposition of two or four monomers of the molecule can generate a catalytically active channel for the selective formation and influx of its enzymatic product. Recognizing the relevance of the CD38 protein in cellular homeostasis and the importance of oligomerization in its functional diversity, the present work aimed to predict the preferential orientation of human CD38 tetramerization with its extracellular polypeptide chain by means of molecular docking. A non-directed docking method (ClusPro) was applied to generate structures, but both dimeric and tetrameric structures were incompatible with an association in the cell membrane. A directed docking method (HADDOCK 2.2) was applied and in this, experimental information from the literature and crystals of the CD38 protein were of high importance in targeting the active residues. As a result, was demonstrated the importance of the $\alpha$-helix 1 regions in the formation of dimmers and $\alpha$-helices 2, 4, 6 and 9, as well as the loop region between the $\beta 5$ chain and $\alpha$-helix 8 , in the formation of tetramers compatible with the membrane association and energetically possible, as classified by the HADDOCK 2.2 method. The tetrameric structures, created by the docking directed with HADDOCK 2.2, form a pocket between the dimmers. Such a region, in the membrane-inserted protein, could be important for the influx of the CD38 protein's catalytic product. This pocket region was proposed in the literature through experimental and functional data. It is considered the importance of studies, both experimental and in silico, that analyze the formation of tetramers and their three-dimensional structure, in addition to experiments that can identify, as by means of conformational antibodies, the dimmers and tetramers of the CD38 protein.

Key words: CD38 protein. Tetramerization. Molecular docking. ClusPro. HADDOCK. 


\section{LISTA DE FIGURAS}

Figura 1 - Representação esquemática de parte do cromossomo 4 humano................................12

Figura 2 — As múltiplas reações enzimáticas catalizadas por CD38.........................................16

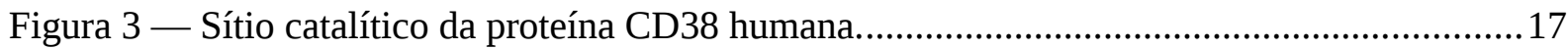

Figura 4 — Estrutura secundária da proteína CD38_.................................................................22

Figura 5 — Estrutura geral da CD38 humana em sua forma solúvel (shCD38)...........................23

Figura 6 - Fluxograma do processo de obtenção dos complexos da CD38 e análises

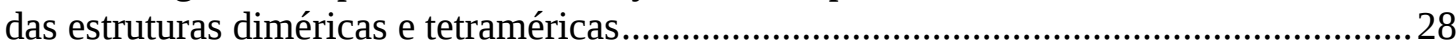

Figura 7 — Estrutura melhor classificada do dímero de hCD38 (CD38 humana) ......................33

Figura 8 - Estruturas criadas por meio de docking não-direcionado com o software

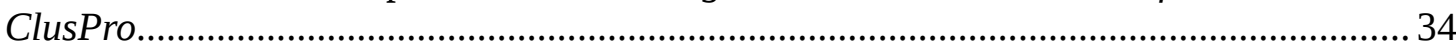

Figura 9 — Cristal da proteína CD38 de camundongo (2eg9)...................................................35

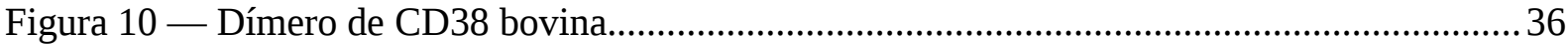

Figura 11 - Estrutura da Aplysia ADP-ribosyl cyclase (1LBE) e do domínio

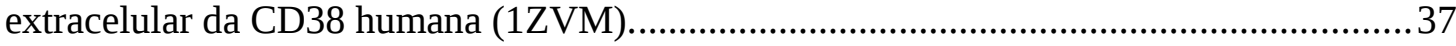

Figura 12 - Estrutura classificada como energeticamente mais favorável entre as geradas pelo docking direcionado com HADDOCK 2.2 da hCD38.

Figura 13 - Caracterização da interface de interação entre os monômeros da hCD38 na formação do dímero.

Figura 14 —Proposta envolvendo a existência de três diferentes regiões de interação entre os monômeros da proteína CD38 humana..

Figura 15 - Caracterização da interface de interação entre os monômeros da mCD38 no cristal 2eg9.

Figura 16 - Estruturas geradas pelo docking não-direcionado dos dímeros HADDOCK como o software ClusPro...

Figura 17 - Tetrâmero formado por meio de docking direcionado com o software HADDOCK2.2. 46

Figura 18 - Interface de interação (região em preto) entre os resíduos responsáveis pela estabilização do tetrâmero de hCD38.

Figura 19 - Estrutura de menor energia criada por meio de docking com software HADDOCK 2.2. 
Figura 20 - Estrutura de menor energia criada por meio de docking com software HADDOCK 2.2.

Figura 21 - Alinhamento estrutural entre 5 estruturas tetraméricas geradas no segundo docking por meio do software HADDOCK 2.2.

Figura 22 — Perfil de interação entre os tetrâmeros e resíduos da interface responsáveis pela estabilização das estruturas tetraméricas geradas no primeiro e segundo docking.

Figura 23 - Interação entre as regiões da proteína mCD38 (2eg9).

Figura 24 - Parte do tetrâmero formado por meio do docking direcionado com HADDOCK 2.2. 


\section{LISTA DE TABELAS}

Tabela 1 - Distribuição da proteína CD38............................................................................ 14

Tabela 2 — Parâmetros energéticos avaliados pelo HADDOCK do cluster 2...........................38

Tabela 3 - Regiões e resíduos definidos como ativos no direcionamento para o primeiro docking direcionado com HADDOCK................................................................45

Tabela 4 - Parâmetros energéticos avaliados pelo HADDOCK do cluster 1..............................47

Tabela 5 - Regiões e resíduos definidos como ativos no direcionamento para o segundo docking direcionado com HADDOCK..................................................................47

Tabela 6 - Parâmetros avaliados pelo HADDOCK 2.2 da estrutura tetramérica melhor classificada por seu perfil energético. 


\section{SUMÁRIO}

1. INTRODUÇÃO 11

1.1. Localização e Estrutura do Gene da CD38 12

1.2. Distribuição Tecidual da CD38 13

1.3. Função Biológica da proteína CD38 15

1.3.1 Função enzimática $\quad 15$

$\begin{array}{ll}\text { 1.3.2 CD38 como receptor } & 17\end{array}$

1.4. Envolvimento da CD38 em Patologias Humanas 18

1.4.1 Leucemia Linfocítica Crônica (CLL) 18

1.4.2 Mieloma múltiplo (MM) 19

1.4.3 Leucemia Promielocítica Aguda (APL) 20

1.4.4 Infecção pelo HIV

1.5. Estrutura da Proteína CD38 21

1.6. Oligomerização da CD38 22

1.7 Docking Molecular $\quad 25$

1.7.1 Docking Rígido e Docking Flexível 25

2. OBJETIVO 27

3. MATERIAL E MÉTODOS 28

$\begin{array}{ll}3.1 \text { ClusPro } & 29\end{array}$

3.2 HADDOCK 31

3.3 Visualização e análise estrutural dos dímeros e tetrâmeros 32

4. RESULTADOS E DISCUSSÃO 33

4.1 Dímeros formados por docking molecular não-direcionado 33

4.1.1 ClusPro 33

4.2 Dímeros formados por docking molecular direcionado 37

4.2.1 HADDOCK $2.2 \quad 37$

4.2.1.1 Cristal de mCD38 (2EG9) e resíduos de interação 40

4.2.1.2 Evidências experimentais da formação de dímeros por meio das $\alpha$ hélices 1 da proteína CD38

4.3 Tetrâmeros formados por docking não-direcionado 43

4.3.1 ClusPro $\quad 44$

4.4 Tetrâmeros formados por docking direcionado $\quad 45$

4.4.1 HADDOCK $2.2 \quad 45$

4.4.2 Evidências da tetramerização 52

4.4.3 Estrutura do sítio ativo da CD38 e bolsão catalítico 54

5. CONCLUSÃO 56

6. REFERÊNCIAS 


\section{INTRODUÇÃO}

A glicoproteína CD38 pertence a uma família de enzimas conservada evolutivamente. Entre os produtos de sua ação enzimática está o segundo mensageiro cADPR (ADP-ribose cíclico), reconhecido como um potente mobilizador dos estoques de cálcio intracelular e envolvido na regulação da homeostase deste íon em muitos tipos celulares, desde plantas a mamíferos (FRANCO et al., 1998).

A proteína CD38 possui uma história compartilhada com várias outras moléculas, identificadas dentro de um projeto que visou examinar moléculas de superfície celular de leucócitos humanos usando anticorpos monoclonais murinos (mAbs), reagentes que se tornaram disponíveis no final da década de 1970 (QUARONA et al., 2013). Os estudos foram organizados por uma série de oficinas internacionais conhecidas como Human Leucocyte Differentiation Antigens (HLDA) Workshops (ZOLA; SWART, 2005).

A primeira oficina do HLDA forneceu uma solução para questões sobre a organização multi-laboratório, testes cegos e a análise comparativa de anticorpos (ZOLA; SWART, 2005). Quando as oficinas do HLDA começaram, os anticorpos monoclonais contra marcadores de leucócitos eram relativamente novos e novos anticorpos estavam sendo produzidos em vários laboratórios. Naquele momento, tanto as sondas como os alvos eram desconhecidos, levando os cientistas envolvidos a formularem estratégias originais para identificar a estrutura e as funções das moléculas-alvo. O Leukocyte Workshop adotou uma estratégia que provou ser bem sucedida nos estudos de HLA: quando dois ou mais mAbs reagiam com o mesmo alvo, foi dito formando um cluster centrado em uma molécula desconhecida. Assim, essa abordagem (Cluster Designation, CD) possibilitou a identificação de uma diversidade de moléculas de superfície em poucos anos. No entanto, foram necessários muitos anos mais para identificar as funções exercidas pela maioria dessas moléculas in vivo, um esforço que ainda está longe de ser concluído (QUARONA et al., 2013).

A CD38 foi identificada por E. L. Reinherz e S. F. Schlossman (Dana-Farber Cancer Center, Boston, MA) num trabalho que utilizou uma série de anticorpos monoclonais para definir três estágios discretos de diferenciação de células $\mathrm{T}$ intra-tímicas humanas (REINHERZ et al., 1980). Nesta pesquisa pioneira, foi realizada uma análise detalhada da superfície celular por meio de anticorpos monoclonais, como parte de sua busca por moléculas que atuam como receptores de células $\mathrm{T}$ e transdutores de sinais induzidos pelo encontro com antígenos específicos. Os dados finais sugeriram a possibilidade de definir 
estágios de diferenciação de células $\mathrm{T}$ que podem estar relacionados a neoplasias destas células em seres humanos (REINHERZ et al., 1980). Ainda, este trabalho resultou na definição de uma vasta gama de moléculas, incluindo, por exemplo, CD4 e CD8, algumas delas desempenhando papel como reguladores metabólicos (CD71 / TFR-1) e várias outras, como CD38, servindo como marcadores para o estudo de timócitos, células $\mathrm{T}$ ativadas e tecidos selecionados (MALAVASI et al., 2008).

\subsection{Localização e Estrutura do Gene da CD38}

O gene da CD38 humana foi mapeado, por hibridação in situ de fluorescência, para banda p15 do cromossomo 4 (4p15) (Figura 1) como um gene de cópia única (NAKAGAWARA et al., 1995). Sua organização foi determinada comparando a sequência genômica com uma sequência de cDNA isolado sem a cauda poli-A por Jackson e Bell (1990). Por meio deste estudo, foi demonstrado que o gene CD38 continha 8 exons. Os exons 1, 2, 3, 4, 5, 6, 7 e 8 têm 308, 130, 136, 86, 74, 93, 87 e 466 pb de comprimento, respectivamente (NATA et al., 1997). Aproximadamente 98\% dos 77 kb do gene da CD38 é composto por sequências intrônicas. O segundo maior exon da CD38, o exon 1 codifica a região 5'-UTR do RNA mensageiro deste gene, seu sítio de início de tradução, as regiões intracitoplasmáticas e transmembranares e os 33 aminoácidos proximais da membrana da região extracelular (SACCUCCI; MALAVASI, 2000; NATA et al., 1997; FERRERO).

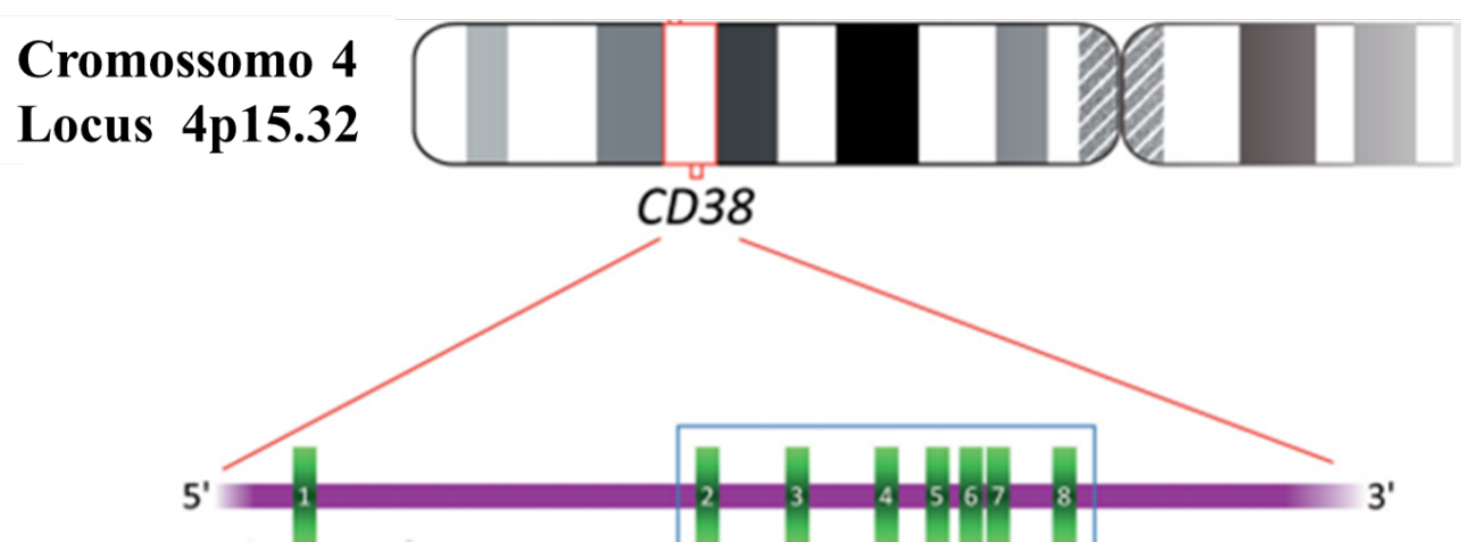

Figura 1. Representação esquemática de parte do cromossomo humano 4, com atenção para localização do gene da CD38 e organização de seus exons. Fonte: Modificado de Quarona e col. (2013). 


\subsection{Distribuição Tecidual da CD38}

A expressão da proteína CD38 foi observada pela primeira vez em timócitos e linfócitos T (BHAN et al., 1980). Posteriormente, novos estudos levaram a uma noção revisada da distribuição da molécula, e a expressão da CD38 agora é considerada praticamente onipresente, pelo menos no sistema imunológico, com níveis de expressão variáveis (QUARONA et al., 2013; MALAVASI et al., 2008). No entanto, o mecanismo de ação subjacente da expressão da molécula em diferentes linhagens celulares ainda não está totalmente esclarecido.

Estudos posteriores (MALAVASI et al., 2008; FERNÀNDEZ et al., 1998), indicaram que a CD38 também está amplamente expressa fora do sistema imunológico, muitas vezes como uma molécula citoplasmática e nuclear (FERNÀNDEZ et al., 1998). Formas funcionalmente ativas da CD38 humana foram identificadas por purificação da membrana externa de eritrócitos humanos solubilizados, num procedimento de purificação que envolveu três passos de cromatografia sequencial em hidroxilapatita, $\mathrm{Cu}++$ imobilizado e resinas de anticorpo monoclonal anti-CD38 imobilizadas (ZOCCHI et al., 1993). Entre os tecidos sólidos, CD38 é expressa por células epiteliais prostáticas normais e células de ilhotas pancreáticas (KRAMER et al., 1995). A expressão desta molécula também foi detectada no corpo celular e dendritos de muitos neurônios, como as células cerebelares de Purkinje (MIZUGUCHI et al., 1995), nos astrócitos de rato (VERDERIO et al., 2001) e nos terminais nervosos autônomos perivasculares (SMYTH et al., 2006). Outras células CD38+ incluem as células musculares lisas e estriadas (FERNÀNDEZ et al., 1998), túbulos renais (CHINI et al., 1997), células gangliares da retina e córnea (KHOO; CHANG, 1999). Na Tabela 1 estão resumidos dados sobre a distribuição da CD38, estando dividida em tecidos linfóides e nãolinfóides. 
Tabela 1: Distribuição da proteína CD38. Fonte: Modificada de Malavasi e col. (2008).

\begin{tabular}{|l|l}
\hline Tecidos Linfoides & População Celular \\
\hline Sangue & $\begin{array}{l}\text { Células T } \\
\text { Células B } \\
\text { Células mieloides } \\
\text { Células NK } \\
\text { Eritrócitos } \\
\text { Plaquetas }\end{array}$ \\
\hline Sangue do cordão umbilical & $\begin{array}{l}\text { Células T e B } \\
\text { Linfócitos e monócitos }\end{array}$ \\
\hline Medula òssea & Precursores de células plasmáticas \\
\hline Timo & Timócitos corticais \\
\hline Linfonodos & Células B germinais centrais \\
\hline Tecidos Não-linfoides & $\begin{array}{l}\text { Células de Purkinje } \\
\text { Córtex cerebral } \\
\text { Astrócitos } \\
\text { Cerebelo }\end{array}$ \\
\hline Cérebro & $\begin{array}{l}\text { Córnea } \\
\text { Células ganglionares da retina }\end{array}$ \\
\hline Células epiteliares \\
\hline Pâncreas & $\begin{array}{l}\text { Linfócitos intraepiteliais } \\
\text { Linfócitos da lâmina própria }\end{array}$ \\
\hline Músculo & Células beta pancreáticas \\
\hline Ossóstata & $\begin{array}{l}\text { Músculo estriado e liso } \\
\text { Intestino }\end{array}$ \\
\hline
\end{tabular}




\subsection{Função Biológica da proteína CD38}

\subsubsection{Função enzimática}

A identificação da semelhança de sequência entre o antígeno de linfócitos humanos CD38 e a ADPR ciclase de Aplysia (STATES; WALSETH; LEE, 1992) marcou o início das investigações sobre as propriedades enzimáticas da CD38 e seu papel na fisiologia e patologia humana. Pesquisas subsequentes (MALAVASI et al., 2008) revelaram que a CD38 é uma ectoenzima multifuncional envolvida no catabolismo de NAD+ e NADP+ (Figura 2). Os dois principais substratos da molécula identificados (NAD+ e NADP+) são utilizados pela CD38 na geração de potentes compostos de mobilização de Ca2+ intracelular como o cADPR (ADP - ribose cíclico), NAADP (Ácido nicotínico adenina dinucleotídio fosfato) e ADPR (ADP ribose). Seu principal produto, ADPR, pode ser covalentemente ligado à proteínas, com potencial para modificar sua função (MALAVASI et al., 2008). Em condições ácidas, CD38 catalisa a geração de NAADP a partir de NADP+ (AARHUS et al., 1995). A importância destas vias enzimáticas foi demonstrada não apenas no sistema imunológico, mas também nos tecidos e órgãos, incluindo útero, brônquios, pâncreas e rim (GUSE, 1999).

As moléculas produzidas por CD38 (cADPR, ADPR e NAADP) participam da mobilização de Ca2+ ligando-se a diferentes receptores e canais envolvidos na regulação do fluxo citoplasmático deste íon, ativando vias de sinalização críticas para vários processos biológicos como, por exemplo, proliferação de linfócitos (GUSE et al., 1999; MORRA et al., 1998), contração muscular cardíaca (MÉSZÁROS; BAK; CHU, 1993) e intestinal (KUEMMERLE; MAKHLOUF, 1995), e liberação de insulina induzida por glicose no pâncreas (TAKASAWA et al., 1993a). O papel da CD38 e de seus produtos na regulação de uma ampla gama de funções fisiológicas é indicado pelos múltiplos defeitos revelados nos camundongos knock-out CD38 (KO) (MALAVASI et al., 2008). Jin e col. (2007) revelaram que a CD38 tem um papel fundamental na liberação de neuropeptídeos, regulando de forma crítica os comportamentos maternos e sociais e pode ser um elemento em transtornos do desenvolvimento neurológico, estando seu defeito ligado ao comprometimento da quimiotaxia neutrofílica, liberação defeituosa de oxitocina e comportamento social aberrante.

Takasawa e col. (1993b) mostraram que o ADP-ribose cíclico (cADPR) pode ser gerado em células $\beta$ pancreáticas por estímulo de glicose, servindo como um segundo mensageiro para a mobilização de $\mathrm{Ca} 2+$ no retículo endoplasmático no processo de secreção 
de insulina. Além disso, foi demonstrado que o ATP gerado no metabolismo da glicose em células $\beta$ inibe a atividade de hidrólise de cADPR, resultando no aumento da formação desta molécula. Esses achados indicam um papel para CD38 na síntese e hidrólise da cADPR no processo de secreção de insulina em células $\beta$ pancreáticas (TAKASAWA et al., 1993b).

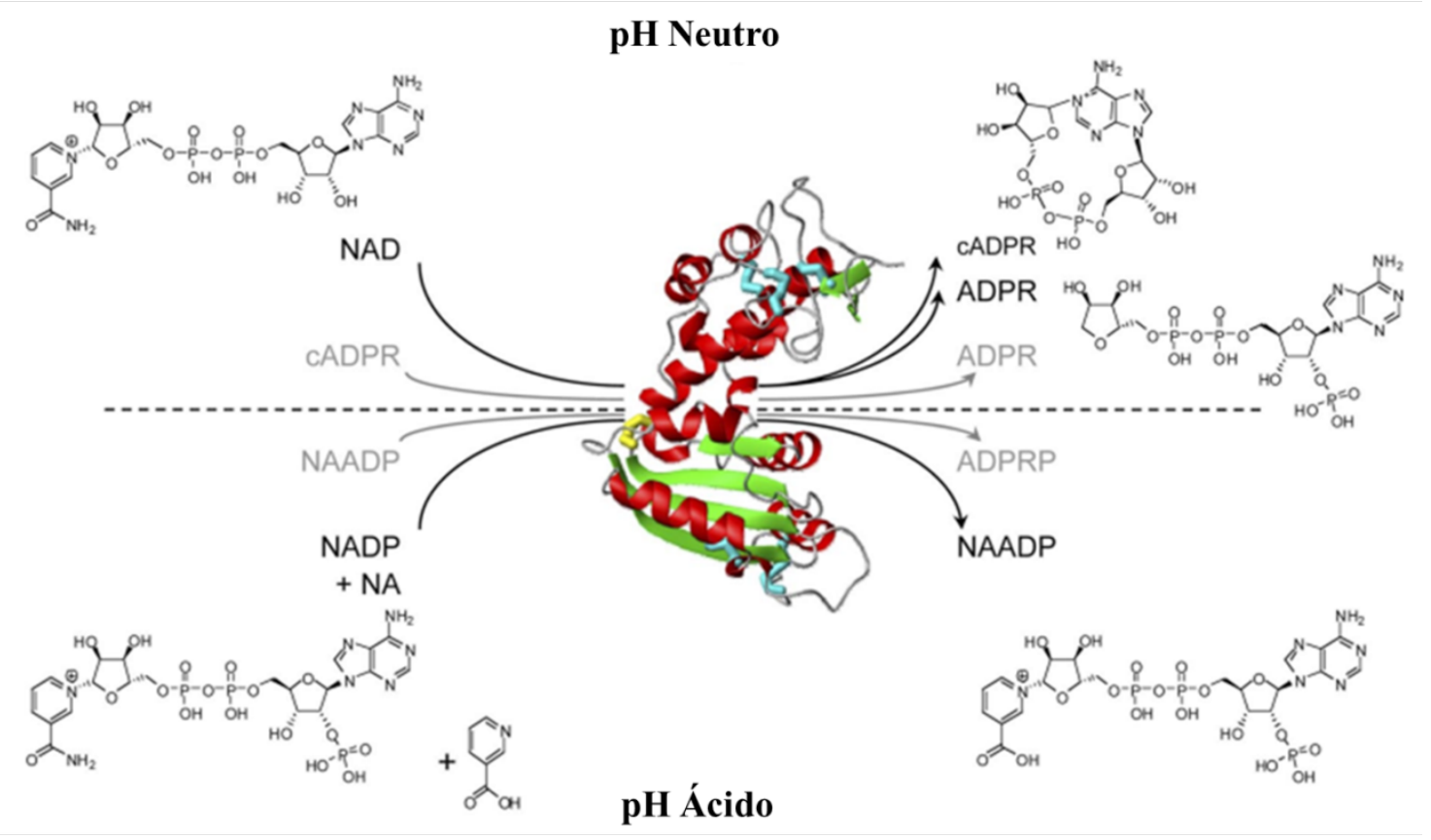

Figura 2. As múltiplas reações enzimáticas catalizadas por CD38. A estrutura química dos substratos NAD e NADP (à esquerda) e produtos cADPR, ADPR e NAADP (à direita) das reações são mostradas. Fonte: Modificado de Malavasi e col. (2008).

\subsubsection{Sítio Catalítico da CD38}

Foi identificado que todas as funções ligadas à ação enzimática da CD38 são realizadas por um único sítio ativo (MUNSHI et al., 2000; GRAEFF et al., 2001). Portanto, as características estruturais desse sítio podem fornecer informações sobre a multifuncionalidade da enzima.

Na estrutura cristalina, o sítio ativo da CD38 (Figura 3) está localizado entre dois domínios distintos e é construído pelas hélices $\alpha 5$ e $\alpha 6$ do domínio $\mathrm{N}$-terminal e hélice $\alpha 7$ e cadeia $\beta 5$ do domínio C-terminal (LIU et al., 2005). 


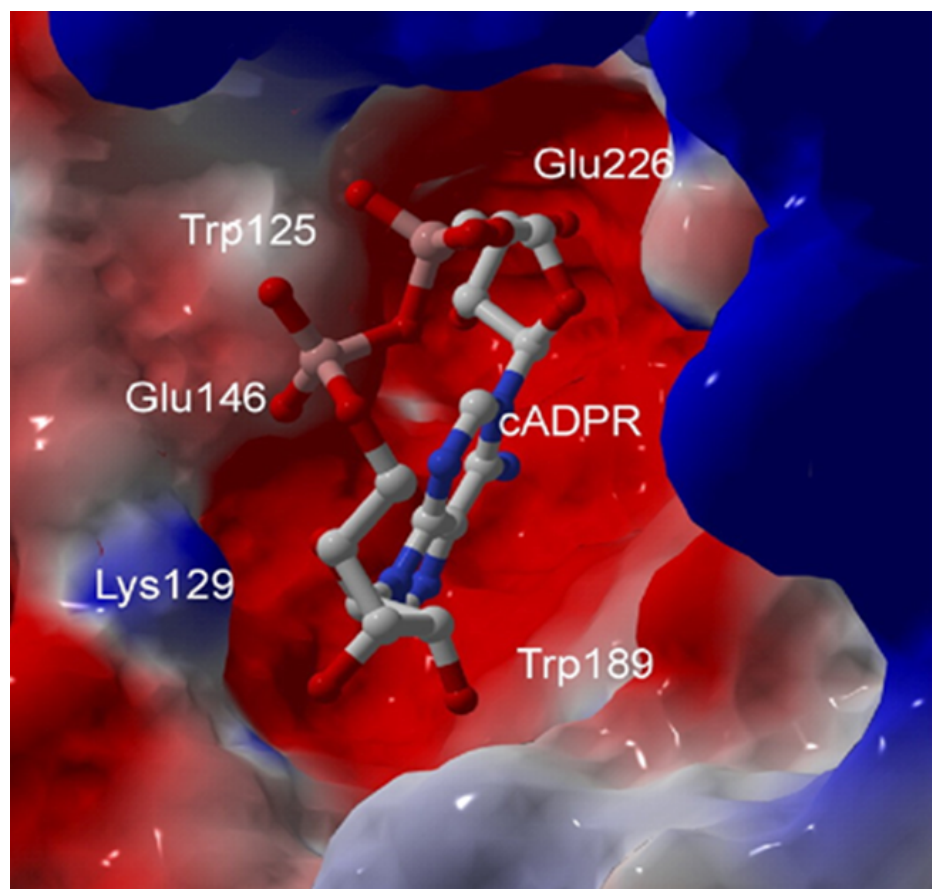

Figura 3. Sítio catalítico da proteína CD38 humana. Na figura está representado o bolsão do sítio de catálise da CD38 juntamente ao cADPR, produto enzimático da proteína, e os resíduos de aminoácidos responsáveis por sua função catalítica. Fonte: Modificado de Liu e col. (2005).

As posições dos resíduos Glu226, Trp125 e Trp189, que são essenciais para a atividade catalítica da enzima (MUNSHI et al., 2000), são altamente conservadas e estão essencialmente fixas nestes elementos estruturais secundários. Todos estes resíduos são conservados na família das ADP-ribosil ciclases e possuem uma conformação muito semelhante e representam, assim, uma característica estrutural da família. Trp125 e Trp189 são sugeridos como os resíduos responsáveis pelo reconhecimento e posicionamento do substrato por interações hidrofóbicas (MUNSHI et al., 2000). Glu226 é o resíduo catalítico que participa da formação da estrutura intermediária na catálise (SUAVE et al., 2000) e sua mutação compromete as atividades catalíticas da proteína CD38 (MUNSHI et al., 2000).

\subsubsection{CD38 como receptor}

Uma função inicial atribuída à CD38 foi a regulação da ativação e proliferação de linfócitos $\mathrm{T}$ humanos. A identificação de um primeiro ligante foi obtida explorando a observação de que os linfócitos $\mathrm{T}$ humanos tendem a aderir-se às células endoteliais (DIANZANI; MALAVASI, 1995). Em experimentos que bloqueiam essa adesão concluiu-se que a proteína CD31, também conhecida como PECAM-1, um membro da superfamília de 
imunoglobulina (Ig), crucial para a adesão e transmigração de leucócitos, era um ligante nãosubstrato para CD38 (NEWMAN, 1999). Mais tarde, demonstrou-se que as interações entre CD38 e CD31 desencadeiam a mesma cascata de sinalização e recapitulam os eventos biológicos observados usando mAbs agonistas (HORENSTEIN et al., 1998; DEAGLIO et al., 1996).

A interação entre CD38 e CD31 é crucial para a migração de leucócitos através do endotélio (DEAGLIO et al., 1998). O crosstalk CD38 / CD31 foi amplamente analisado em vários ambientes diferentes que variam de células $T$ para $B$, células $\mathrm{NK}$ e mielóides, em condições normais e patológicas (DEAGLIO et al., 2000). Os sinais mediados por CD38 são regulados em níveis distintos, como os relacionados à organização ultraestrutural da molécula e o posicionamento na membrana, na localização dinâmica da CD38 nos microdomínios lipídicos dentro da membrana plasmática, as associações laterais com outras proteínas, que variam de acordo com a linhagem celular e a associação com complexos de sinalização (DEAGLIO et al., 2007).

\subsection{Envolvimento da CD38 em Patologias Humanas}

A proteína CD38 mostra-se um importante marcador para doenças como diabetes, asma, leucemia e mieloma por produzir moléculas que aumentam a resistência de células tumorais a drogas anticâncer e na patogênese da infecção pelo vírus da imunodeficiência humana (HIV). A disfunção da atividade da CD38 está associada à deficiência da resposta imune, distúrbios metabólicos e modificação do comportamento em camundongos (MALAVASI et al., 2008).

\subsubsection{Leucemia Linfocítica Crônica (CLL)}

A Leucemia Linfocítica Crônica (CLL) é um tipo de leucemia mais comum em adultos que resulta do acúmulo de linfócitos B pequenos (CD19+ / CD5+ / CD23+) no sangue, medula óssea (BM), linfonodos (LN) e outros tecidos linfóides (CHIORAZZI; FERRARINI, 2011). A expressão da CD38 apresenta-se, em geral, aumentada em células CLL, fato associado a um estágio avançado da doença, assim como uma maior incidência de linfadenopatia, alto risco citogenético, menor tempo de duplicação de linfócitos e menor resposta à terapia. 
A proteína CD38 é uma componente da rede molecular que fornece sinais de crescimento e sobrevivência às células CLL (MALAVASI et al., 2011). Além de ser um fator prognóstico, a proteína CD38 atua como receptor em células leucêmicas e seus sinais são mediados por ZAP70, outro fator prognóstico negativo para a doença, e um fator limitante para a ativação mediada por CD38 (DEAGLIO et al., 2003).

A CD38 influencia as respostas migratórias e contribui para a recirculação de células neoplásicas do sangue para órgãos linfóides ao trabalhar em associação com quimiocinas e seus receptores, principalmente CXCL12 / CXCR4 (VAISITTI et al., 2010) e com moléculas de adesão específicas pertencentes à família das integrinas (ZUCCHETTO et al., 2009). A interação da CD38 com a proteína CD31 desencadeia a ativação de uma via de sinalização intracelular e esses sinais aumentam a quimiotaxia e a proliferação de células B neoplásicas. Juntas, esta evidência contribui para a visão atual da CLL como uma doença em que o microambiente do hospedeiro promove o crescimento de células leucêmicas e também controla a aquisição sequencial e a acumulação de alterações genéticas (QUARONA et al., 2013; MALAVASI et al., 2011).

\subsubsection{Mieloma múltiplo (MM)}

O Mieloma Múltiplo (MM) é uma doença maligna caracterizada pelo acúmulo de células plasmáticas monoclonais na medula óssea, uma alta concentração de Igs monoclonais no soro e urina e lesões ósseas líticas. A proliferação de células plasmáticas neoplásicas no MM interfere com a produção normal de células sanguíneas, enquanto as Igs monoclonais prejudicam a imunidade humoral (KUMAR et al., 2017; QUARONA et al., 2013).

Foram registrados muitos progressos na década passada na compreensão da biologia da doença e nas abordagens de tratamento individualizado. Novas classes de drogas, como inibidores de proteassoma e drogas imunomoduladoras, se juntaram aos tradicionais corticosteróides, agentes alquilantes e antraciclinas e juntamente com o transplante autólogo de células tronco hematopoiéticas, levaram a respostas clínicas positivas e duradouras (KUMAR et al., 2017).

A proteína CD38 desempenha um papel significativo no MM ao estar presente na membrana de células plasmáticas (normais e tumorais) (KRIEGSMANN et al., 2018). As células de mieloma e linhagens derivadas apresentam receptores para o hormônio oxitocina (OT) e, em experimentos com modelos murinos, a proteína CD38 demonstra ação como 
reguladora dos níveis desse hormônio em fluidos biológicos, o que conecta a ação da CD38 com a ativação de receptores OT em células de mieloma múltiplo (COLAIANNI et al., 2011). A CD38 também é expressa por osteoblastos e osteoclastos, tipos celulares que liberam OT, e, nestas células, a CD38 implementa sinais que conduzem à liberação de IL-6 e à inibição da reabsorção óssea, fato ligado ao processo de inibição da perda óssea que está presente em pacientes com mieloma múltiplo (IQBAL; ZAIDI, 2006).

À luz dessas considerações, as células plasmáticas, normais e tumorais, e os nichos ósseos são importantes áreas de testes para avaliar a presença de uma conexão entre ectoenzimas e neuropeptídeos (KRAUSE; SCADDEN; PREFFER, 2013). Os nucleosídeos representam sinais adicionais para aqueles liderados por citocinas / quimiocinas e outros reguladores convencionais como o ATP e NAD+, operando em loco, podem complementar os sistemas reguladores fisiológicos das células plasmáticas (QUARONA et al., 2013).

\subsubsection{Leucemia Promielocítica Aguda (APL)}

A Leucemia Promielocítica Aguda (APL) é um subtipo de leucemia aguda, que causa uma interrupção da diferenciação de leucócitos no estágio de promielócitos, um precursor de granulócitos (ADAMS; NASSIRI, 2015). O ácido retinóico (AR) está incluído em protocolos terapêuticos quanto à sua capacidade de induzir a diferenciação de células leucêmicas em granulócitos maduros. Essa terapia pode estar associada à síndrome do ácido retinóico (RAS), uma manifestação clínica caracterizada por febre, dispneia e edema pulmonar (GAO; CAMACHO; MEHTA, 2007).

Os granulócitos normais são CD38-, enquanto as células APL tratadas com RA expressam altas quantidades da molécula (MEHTA; SHAHID; MALAVASI, 1996). A expressão aumentada da CD38 em células leucêmicas aumenta sua propensão para interagir com CD31, expressa por células endoteliais pulmonares, resultando em uma produção local de citocinas inflamatórias, apoptose de células endoteliais e, eventualmente, contribuindo para o desenvolvimento de RAS (GAO; CAMACHO; MEHTA, 2007). 


\subsubsection{Infecção pelo HIV}

A expansão do subconjunto de linfócitos CD8+ / CD38+ foi uma alteração observada com frequência antes da detecção de anticorpos contra o HIV e níveis diminuídos de células CD4+, características ligadas à infecção pelo vírus, em indivíduos com risco de desenvolver AIDS (GIORGI; DETELS, 1989). Essas taxas elevadas de linfócitos T CD8+ / CD38+ prevêem a progressão da doença em adultos infectados (GIORGI et al., 1994). Mesmo sendo caracterizada pelo aumento da expressão da CD38, a infecção pelo HIV, aparentemente, não é a causa direta deste aumento como reportado por Savarino e col. (2000).

A terapia anti-retroviral altamente ativa (tradução de Highly Active Antiretroviral Therapy, HAART), o tratamento padrão na infecção pelo HIV em adultos e na pediatria, leva a supressão viral com diminuição da expressão da CD38, aumento das contagens de linfócitos T CD4+, recuperação de funções imunes contra infecções oportunistas e um bom resultado clínico na maioria dos pacientes (QUARONA et al., 2013).

\subsection{Estrutura da Proteína CD38}

CD38 foi inicialmente relatada como uma única cadeia de 45 KDa ocasionalmente associada a uma molécula de $12 \mathrm{kDa}$, tornando-se uma remanescente de uma família de moléculas de Antígenos de Leucócitos Humanos (HLA) de classe I conhecidas na época como T10 (TERHORST et al., 1981). O tratamento com endoglicosidase-H reduziu a massa da CD38 em aproximadamente 20\%, evidenciando uma banda mais larga centrada a $36 \mathrm{kDa}$. Assim, a proteína CD38 revelou-se como uma glicoproteína compreendendo duas a quatro cadeias de oligossacarídeo ligadas ao nitrogênio de resíduos de asparagina, contendo resíduos de ácido siálico. No entanto, as várias células CD38+ ou linhagens celulares não revelaram diferenças bioquímicas aparentes nesta proteína (MALAVASI et al., 2008; ALESSIO et al., 1990).

A estrutura geral da molécula CD38 pode ser dividida em dois domínios distintos ( $\mathrm{N}$ e C-terminal) (Figura 4). O domínio NH2-terminal (resíduos 45-118 e 144-200) é formado por um pacote de $\alpha$ hélices (1 a 6) e duas pequenas fitas $\beta$ ( $\beta 1$, $\beta$ 3); e o domínio COOH-terminal (resíduos 119-143 e 201-300) consiste em uma folha $\beta$ paralela de quatro cadeias ( $\beta 2$ a $\beta$ 6) e duas pequenas $\alpha$ hélices ( $\alpha 4$ e $\alpha$ 7). Esses dois domínios distintos são conectados por uma região composta por três cadeias peptídicas, incluindo os resíduos 118-119, 143-144 e 200201. Uma ligação dissulfeto (Cys119-Cys201), além dos outros cinco pares de ligações 
dissulfeto (Cys64 - Cys82, Cys99 - Cys180, Cys160 - Cys173, Cys254 - Cys275 e Cys287 Cys296) conservados em membros da família ADPRC (ADP - ribose cíclica), estabiliza ainda mais as conformações relativas dos dois domínios, ligando os peptídeos 118-119 com 200-201 (LIU et al., 2005).

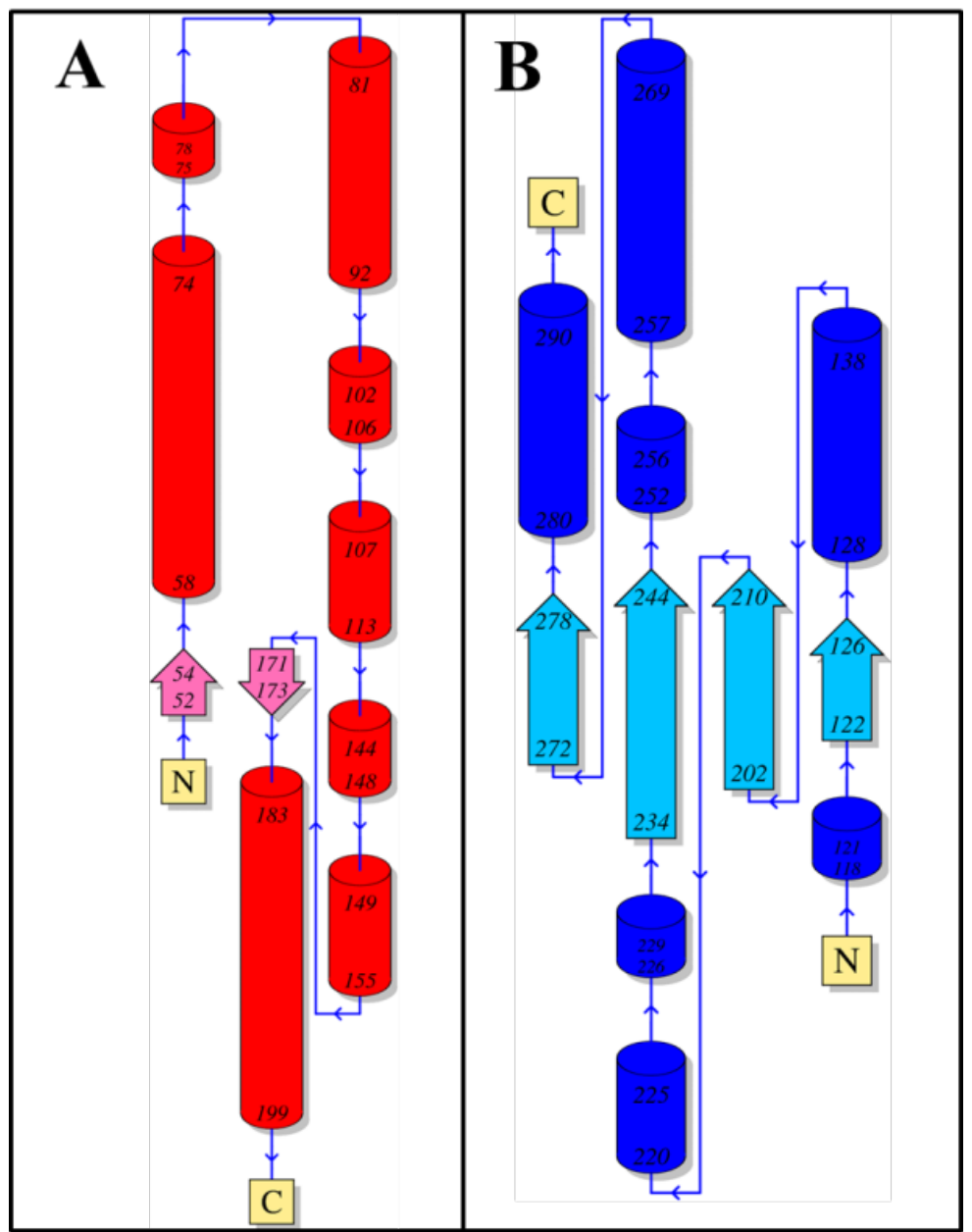

Figura 4. Estrutura secundária da proteína CD38. Em A estão representadas as estruturas secundárias presentes na região $\mathrm{N}$-terminal da proteína. Em B estão representadas as estruturas secundárias presentes em sua região C-terminal. As numerações presentes em ambas as imagens representam o número dos resíduos de aminoácidos das regiões. Em A e B as $\alpha$ hélices estão representadas por cilindros e as folhas $\beta$ por setas.Fonte: UniProt.

\subsection{Oligomerização da CD38}

A proteína CD38 é composta por um pequeno domínio citoplasmático, um domínio transmembrana e um grande domínio extracelular que contém seu sítio catalítico (GELMAN et al., 1993; JACKSON; BELL, 1990). Concentrando-se em regiões especializadas da 
membrana plasmática, CD38 é encontrada em associação com diversos complexos supramoleculares na membrana de leucócitos (FRASCA et al., 2006: DEAGLIO et al., 2003).

A topologia geral do domínio extracelular da CD38 humana (Figura 5) se apresenta de maneira similar em outros membros da família das ADP-ribosil ciclase, estando os resíduos de importância catalítica localizados em posições espacialmente equivalentes (LIU et al., 2005; YAMAMOTO-KATAYAMA et al., 2002; PRASAD et al., 1996). Porém, os membros das ADP-ribosil ciclase apresentam diferenças na forma de associação com a membrana (HARA-YOKOYAMA et al., 2012) e orientação da $\alpha$ hélice 9 na região C-terminal, sendo esta revelada por análise cristalográfica (LIU et al., 2005).

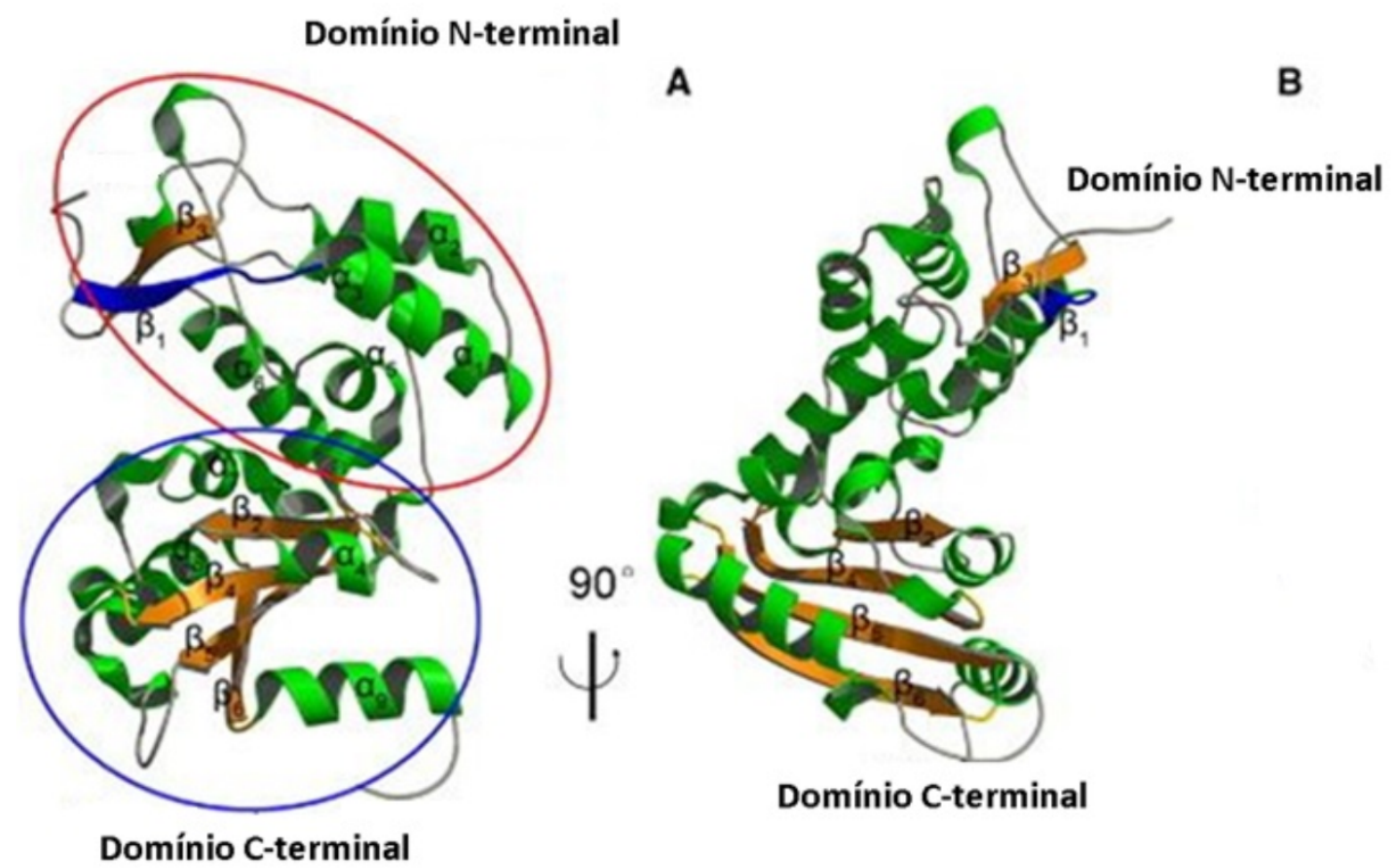

Figura 5. Estrutura geral da CD38 humana em sua forma solúvel (shCD38). Na figura A, são indicadas as regiões N-terminal (círculo vermelho) e C-terminal (círculo azul) da proteína. Em B está apresentada a estrutura de A com rotação horizontal de $90^{\circ}$. Tanto em A quanto em B são representados as estruturas secundárias de $\alpha$ hélices e folhas $\beta$. Fonte: modificado de Liu e col. (2005).

A orientação da $\alpha$ hélice 9 na região C-terminal da CD38 possui papel central na sua dimerização homofílica. Análises bioquímicas demonstraram a formação de dímeros por outros dois integrantes da família da CD38 (Aplysia ribosil ciclase e BST-1) (MUNSHI et al., 1998; SATO et al., 1999), porém a proteína CD38 humana não é capaz de dimerizar por meio do mesmo mecanismo, isto é, alcançando a mesma distribuição espacial molecular da 
extremidade C-terminal, que ocorre nestes outros dois membros de sua família, devido ao impedimento estérico gerado pela orientação da $\alpha$ hélice C-terminal ( $\alpha$ 9) (HARAYOKOYAMA et al., 2012). Embora já tenha sido demonstrada, por peso molecular, a existência da CD38 humana na forma tetramérica (BRUZZONE et al., 1998; FRANCO et al., 1998), supõe-se que a interação homofílica que leva a este estado de agregação ocorra por mecanismos distinto, como os propostos por Hara-Yokoyama e col. (2012), sendo provável que sua estruturação tenha diversidade entre as espécies e seus aspectos estruturais, em sua totalidade e relevância funcional, ainda não tenham sido esclarecidos.

Outro fato importante na indicação de tetramerização da CD38 ocorre durante sua síntese, com a presença de oligossacarídeos com alto teor de manose no resíduo de asparagina 213 (N213). Durante a síntese de proteínas, os glicanos do tipo oligomanose são primeiro processados por $\alpha$-glucosidases e manosidases no retículo endoplasmático e depois são processados em oligossacarídeos de tipo complexo ou híbrido por Nacetilglucosaminiltransferase I na região média do complexo de Golgi (KATO; KAMIYA, 2007). Uma análise do glicano ligado em local específico da CD38 revelou que apenas os oligossacarídeos unidos ao resíduo de N213 permaneceram como o tipo de oligossacarídeo com alto teor de manose.

Dentro do tetrâmero proposto por Hara-Yokoyama e col. (2012) da CD38, o resíduo N213 está disposto no espaço entre o domínio extracelular e a membrana. Esta orientação evitaria o acesso das enzimas de processamento. Em contrapartida, o resíduo N213 é totalmente acessível para as enzimas quando a CD38 está presente como um dímero ou um monômero, indicando, assim, a existência da forma tetramérica da proteína CD38 durante sua síntese na membrana do retículo endoplasmático e posterior direcionamento para o complexo de golgi e membrana plasmática celular (HARA-YOKOYAMA et al., 2012).

É previsto que a tetramerização da CD38 ocorra de forma mais eficiente com seu comprimento total na superfície celular do que os fragmentos de domínio extracelular em solução, provavelmente porque a orientação do domínio extracelular está restrita na superfície da célula enquanto, em solução, a proteína possui ampla possibilidade de movimentação (HARA-YOKOYAMA et al., 2012).

Dados de Franco e col. (1998) sugerem que a justaposição transmembranar de dois ou quatro monômeros da CD38 podem gerar um canal cataliticamente ativo para a formação seletiva e influxo de cADPR, importante na via ligada ao cálcio intracelular responsiva à esta molécula. Por meio da identificação da estrutura do tetrâmero no cristal da CD38 de camundongo (2eg9), foi previsto que todos os locais catalíticos estejam dispostos no espaço 
entre a ectoenzima e a superfície da membrana, abrindo espaço para elucidação do modo funcional da CD38 como ectoenzima (HARA-YOKOYAMA et al., 2012). Deste modo, além das implicações da tetramerização da CD38 como receptor, distribuída amplamente em diversos tecidos, seria esclarecedor determinar se as quatro subunidades justapostas na membrana são a base para a atividade do canal interno para o cADPR produzido.

Porém, apesar das evidências experimentais da formação de dímeros e tetrâmeros da CD38, o cristal utilizado para propor seu modo de interação é proveniente de proteína modificada e, no caso da CD38 de camundongo de Hara-Yokoyama e col. (2012), o truncamento da $\alpha$ hélice 9, modificação estrutural de regiões adjacentes ao domínio Cterminal e as mutações em sítios de glicosilação podem ter papel decisivo no seu modo de interação identificado no cristal. Da mesma forma, outros cristais da CD38 humana não demonstram tal tetramerização, apesar das similaridades de sequência e estrutura entre CD38 de camundongo e humana (HARA-YOKOYAMA et al., 2012).

Desse modo, torna-se necessário expandir as formas de análise da estrutura dos complexos formados pela proteína CD38, assim como a integração entre dados bioquímicos e de experimentos in silico. Dito isso, tendo em vista os questionamentos remanescentes sobre a maneira pela qual os possíveis dímeros e tetrâmeros tomam forma, o presente trabalho buscou analisar por meio de métodos de docking molecular, a formação de dímeros e tetrâmeros da CD38 humana, utilizando para tal, dois diferentes métodos de docking molecular, abrangendo o método não-direcionado e o direcionado.

\subsection{Docking Molecular}

A abordagem de ancoragem (do ingês, docking) molecular pode ser usada para modelar a interação entre uma pequena molécula e uma proteína no nível atômico, diferentes proteínas ou mesmo moléculas de proteína e ácidos nucleicos, o que nos permite caracterizar o comportamento dessas moléculas no sítio de ligação de proteínas alvo e na formação de complexos, bem como elucidar processos bioquímicos fundamentais (MENG et al., 2011).

\subsubsection{Docking Rígido e Docking Flexível}

O docking rígido produz um grande número de conformações ancoradas com complementaridade de superfície favorável, seguido pela classificação das conformações 
usando a energia livre. A abordagem de correlação da transformada rápida de Fourier (em inglês, Fast Fourier Transform, ou FFT) (KATCHALSKI-KATZIR et al., 1992) explora sistematicamente o espaço das conformações ancoradas usando interações eletrostáticas (MANDELL et al., 2001), mas o potencial é restrito a uma forma de função de correlação. Posteriormente, as correlações polares de Fourier foram usadas para acelerar a busca por conformações de baixa energia (RITCHIE; KEMP, 2000). Além disso, outras abordagens, como conceitos de visão computacional, processo de modelagem e replicação da visão humana usando software e hardware (WOLFSON; NUSSINOV, 2000), operações booleanas (PALMA et al., 2000) e os algoritmos genéticos (GARDINER; WILLETT; ARTYMIUK, 2001) também foram usados na predição das estruturas de complexos moleculares (MENG et al., 2011).

Em estudos de docking rígido, os ligantes são encaixados livremente em um receptor rígido. No entanto, tornou-se cada vez mais claro que a flexibilidade da cadeia lateral desempenha um papel crucial nos complexos. Estas alterações permitem que o receptor altere o seu local de ligação de acordo com a orientação do ligante. O ligante orienta-se em um espaço de variáveis translacionais, rotacionais e conformacionais no ambiente do receptor (JACKSON; GABB; STERNBERG, 1998).

O objetivo do docking de proteína-proteína é prever a estrutura de um complexo a partir das estruturas individuais de seus componentes, que podem ser determinadas experimentalmente ou preditas. O processo de docking envolve dois passos básicos: a predição da conformação, posição e orientação dos ligantes e a avaliação da afinidade da ligação por meio de pontuações utilizadas, posteriormente, para a classificação das estruturas ancoradas. O docking sem nenhuma suposição ou conhecimento sobre a localização dos sítios de ligação de uma proteína é chamado "blind docking". Quando o docking é direcionado, são determinados resíduos ativos e passivos no processo anterior aos dois passos básicos (MENG et al., 2011).

Ao longo da simulação, os resíduos classificados como ativos são direcionados para fazer parte da interface, se possível, de outra forma incorrerão penalidades de pontuação. Os resíduos passivos são aqueles que podem contribuir para a interação, mas não são considerados para penalidades de pontuação, caso esses resíduos não pertençam à interface (VAN ZUNDERT et al., 2016). Portanto, uma seleção cuidadosa de quais resíduos são ativos e quais são passivos é fundamental para o sucesso do docking (VAN ZUNDERT et al., 2016). 


\section{OBJETIVO}

\subsection{Objetivo Geral}

Tendo em vista a relevância da proteína CD38 na homeostase celular e a importância do seu processo de oligomerização na sua diversidade funcional, o presente trabalho teve por objetivo prever a orientação preferencial da tetramerização homofílica da CD38 humana com sua cadeia polipeptídica da porção extracelular por meio de docking molecular.

\subsection{Objetivos específicos}

a) Obtenção de dímeros da CD38 por meio de docking proteína-proteína usando como base a estrutura tridimensional da porção extracelular disponível no banco de dados de proteínas (PDB).

b) Obtenção de tetrâmeros da CD38 por meio do docking dos dímeros obtidos em etapa anterior deste mesmo trabalho e que demonstrem compatibilidade com a associação na membrana celular ao direcionar as regiões $\mathrm{N}$-terminal para mesma área.

c) Analise, dentre os modelos gerados, da formação tetramérica de maior viabilidade de acordo com parâmetros físico-químicos e informações de estudos experimentais, assim como a compatibilidade de associação de ambos os monômeros na membrana celular.

d) Comparação do modelo de maior viabilidade com o modelo previsto na literatura. 


\section{MATERIAL E MÉTODOS}

A estrutura terciária da porção extracelular da CD38 humana (código PDB 1yh3) (LIU et al., 2005), utilizada para formação de dímeros e tetrâmeros, foi obtida do Protein Data Bank (PDB) (BERMAN et al., 2000). Na figura 6 estão representadas as atividades realizadas durante o processo de docking proteína-proteína das estruturas tridimensionais da CD38 humana e análises dos complexos gerados.

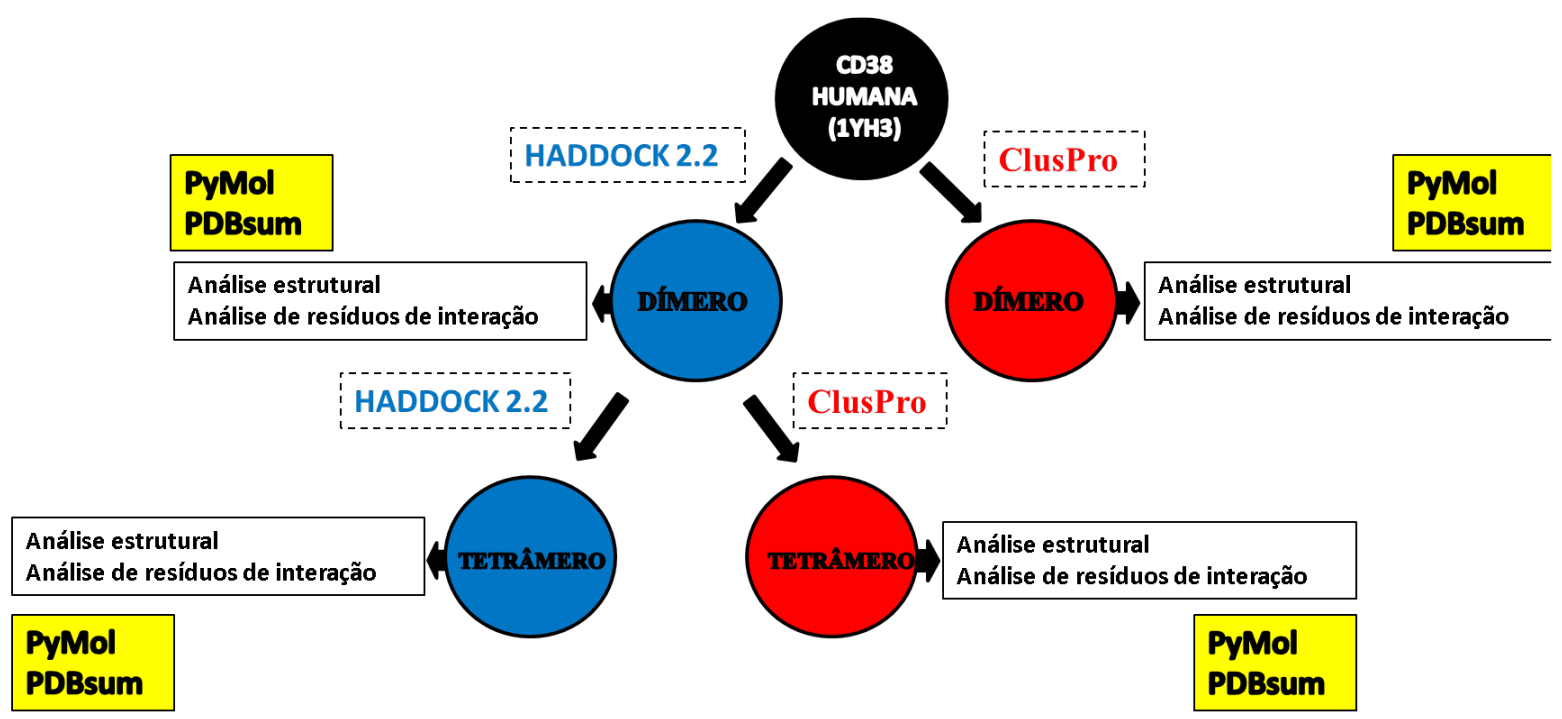

Figura 6: Fluxograma do processo de obtenção dos complexos da CD38 e análises das estruturas diméricas e tetraméricas. Os círculos azuis representam estruturas obtidas por docking direcionado com HADDOCK 2.2. Os círculos vermelhos representam as estruturas obtidas por docking não-direcionado com o servidor ClusPro. Nos retângulos ao lado dos círculos estão representadas as análises feitas e nos quadros em amarelo estão as ferramentas utilizadas para estas análises.

Para escolha dos métodos de docking a serem utilizados no trabalho foi consultada a literatura na área e analisados os métodos de avaliação de técnicas para predição de estruturas de complexos como o CAPRI.

O método CAPRI (sigla em inglês para Avaliação Crítica de Interações PReditas) (LENSINK; VELANKAR; WODAK, 2017) testa os algorítmos de docking que predizem a estrutura do complexo proteína-proteína. CAPRI almeja complexos de proteína-proteína e sua predição inicia-se a partir da estrutura 3D das proteínas que compõem o complexo. No $C A P R I$, os complexos proteína-proteína experimentalmente determinados são mantidos confidenciais pelo comitê organizador, enquanto a comunidade de predição é convidada a 
predizer sua estrutura. CAPRI, assim, avalia os métodos de docking, classificando os que apresentaram maior sucesso na predição correta dos complexos.

De acordo com os experimentos do CAPRI (LENSINK; VELANKAR; WODAK, 2017), o servidor ClusPro foi melhor na ancoragem automatizada de proteínas, equivalente ao melhor grupo preditor humano. HADDOCK (VAN ZUNDERT et al., 2016) e SwarmDock (TORCHALA et al., 2013) foram os melhores logo em seguida.

Assim, o docking proteína-proteína para formação de dímeros e tetrâmeros da CD38 humana foi realizado por meio dos softwares bem avaliados no CAPRI e amplamente utilizados na literatura atual. Neste trabalho, os servidores ClusPro (KOZAKOV et al., 2017) e HADDOCK 2.2 (VAN ZUNDERT et al., 2016) foram utilizados visando dois métodos distintos de docking: o docking não-direcionado e o direcionado, respectivamente.

\subsection{ClusPro}

O ClusPro é um servidor para o docking direto de duas proteínas (KOZAKOV et al., 2017). O servidor executa três etapas computacionais: (1) docking de rígido pela amostragem de bilhões de conformações, (2) agrupamento baseado em RMSD (sigla em inglês para desvio da raiz quadrada média) das 1000 estruturas de menor energia geradas para encontrar os maiores grupos que representarão os modelos mais prováveis do complexo e (3) refinamento de estruturas selecionadas usando minimização de energia (KOZAKOV et al., 2017).

A etapa de docking rígido usa o PIPER, um programa de docking baseado na abordagem de correlação Fast Fourier Transform (FFT) (KOZAKOV et al., 2006). A abordagem FFT, introduzida por Katchalski-Katzir e colaboradores (KATCHALSKI-KATZIR et al., 1992) em 1992, possibilitou o progresso no docking rígido entre proteínas. Neste método, uma das proteínas é colocada na origem do sistema de coordenadas em uma grade fixa, a segunda é colocada em uma grade móvel, e a energia de interação é registrada como uma função de correlação (ou como uma soma de algumas funções de correlação) (KOZAKOV et al., 2017). A eficiência numérica dos métodos deriva do fato de que tais funções de energia podem ser eficientemente calculadas usando Transformadas Rápidas de Fourier (em inglês fast Fourier transform, ou FFT) e resulta na capacidade de amostrar exaustivamente bilhões das conformações das duas interações proteína, avaliando as energias em cada ponto de grade (KOZAKOV et al., 2017). Assim, o algoritmo baseado em FFT permite o docking de proteínas sem qualquer informação inicial sobre a estrutura do complexo. 
Katchalski-Katzir e col. (1992) usaram uma função de pontuação que representava apenas a complementaridade da forma. No entanto, os métodos subsequentes baseados na abordagem de correlação FFT para o docking introduziram funções de pontuação mais complexas e mais precisas que também incluíam termos que representam interações eletrostáticas (GABB; JACKSON; STERNBERG, 1997), ou ambas as contribuições, eletrostática e dessolvatação (CHEN; WENG, 2002). O sucesso dos métodos de docking rígido está intimamente ligado ao fato de que o termo de complementaridade de forma permite algumas sobreposições e, portanto, os métodos são capazes de tolerar diferenças moderadas entre estruturas ligadas e não ligadas (KOZAKOV et al., 2017).

Uma das características distintivas do PIPER, o programa de docking usado na versão atual do ClusPro, é que essa implementação do método de correlação FFT emprega uma função de pontuação que inclui um termo de interação pareada baseado em estrutura e na combinação com os outros termos na função de energia que aumentam substancialmente a precisão do docking, resultando em estruturas mais próximas da nativa (KOZAKOV et al., 2006).

O algoritmo de docking PIPER representa a energia de interação entre duas proteínas usando uma expressão na forma E = w1Erep + w2Eattr + w3Eelec + w4EDARS onde Erep e Eattr denotam as contribuições da repulsão e da atração a energia de interação de van der waals e Eelec é um termo de energia eletrostática (KOZAKOV et al., 2017). EDARS é um potencial baseado na estrutura de emparelhados e ele inicialmente representa contribuições de desolvatação e a energia livre muda devido à remoção de moléculas de água da região (CHUANG et al., 2008). Os coeficientes w1, w2, w3 e w4 definem o peso do termo correspondente e são otimamente selecionados para diferentes tipos de problemas no docking. A menos que especificadas as opções avançadas, o servido gera quatro conjuntos de modelos usando os esquemas de pontuação conhecidos como balanceados, favorecidos eletrostaticamente, favorecidos hidrofobicamente e van der waals + eletrostáticos (KOZAKOV et al., 2017). 


\subsection{HADDOCK}

A maioria dos programas de docking molecular usa a mesma abordagem: uma proteína é fixada no espaço e a segunda é rotacionada e translacionada em torno da primeira (KOZAKOV et al., 2013). Para cada nova configuração, uma pontuação é calculada com base em vários termos, como complementaridade de superfície, interações eletrostáticas, repulsão de van der Waals e assim por diante. A desvantagem desses métodos é que a busca por todo o espaço conformacional da geometria do complexo torna o cálculo pesado, raramente resultando em uma única solução (DOMINGUEZ; BOELENS; BONVIN, 2003).

HADDOCK faz uso de dados de interação bioquímica e / ou biofísica, sendo as informações, sobre os resíduos de interação, introduzidas como restrições de interação ambíguas (do termo em inglês: Ambiguous Interaction Restraints - AIRs) para orientar o processo de docking (DOMINGUEZ; BOELENS; BONVIN, 2003). Após o cálculo, as estruturas são classificadas de acordo com sua energia intermolecular, ou seja, a soma da energia eletrostática (Eelec), van der Waals (Evdw) e das AIRs (EAIR), além do valor para Área de Superfície Enterrada (do inglês Buried Surface Area - BSA). Com os valores energéticos definidos as soluções são pontuadas de acordo com uma combinação linear de termos energéticos, que juntos formam o HADDOCK Score (HS), como exemplificado na equação 1:

$$
\mathrm{HS}=0.01 \mathrm{EvdW}+0.1 \text { Eelec }+1.0 \text { Edesolv }-0.01 \mathrm{BSA}+0.01 \mathrm{EAIR}
$$

As restrições de interação ambíguas (AIRs) são provenientes de qualquer tipo de informação experimental disponível sobre resíduos que estão envolvidos na interação intermolecular. O uso das AIRs permite ao HADDOCK pesquisar todas as configurações possíveis em torno do local de interação definido pelos dados e encontrar o par mais favorável de aminoácidos interagindo entre os resíduos ativos e passivos (DOMINGUEZ; BOELENS; BONVIN, 2003).

HADDOCK foi implementado no sistema de software chamado Crystallography \& NMR System (CNS) (BRÜNGER et al., 1998) para determinação de estruturas cristalográficas e de RMN (Ressonância Magnética Nuclear) e faz uso de scripts python derivados do ARIA, um protocolo de software que integra atribuições automatizadas do efeito nuclear overhauser (NOE) em cálculos de estrutura (LINGE; O’DONOGHUE; NILGES, 2001). 
O protocolo de docking, que requer os arquivos PDB das proteínas individuais e as restrições de interação ambíguas, consiste em três etapas: (i) randomização de orientações e minimização de energia (EM) (ii) anelamento semirígido simulado no espaço do ângulo de torção (TAD-SA) e (iii) refinamento final no espaço cartesiano com solvente. Estes passos são importantes para uma pontuação adequada das conformações resultantes. As estruturas finais são agrupadas usando RMSD (raiz quadrada do desvio médio ou root-mean-square deviation) na interface e os clusters, definidos como um conjunto de pelo menos duas conformações exibindo um iRMSD, resultantes são analisados e classificados de acordo com as suas energias médias de interação (soma de Eelec, Evdw, EAIR) e sua área de superfície média. Em sua utilização, HADDOCK possui parâmetros configurados como padrão, que podem ser modificados pelo usuário para otimizar os protocolos em problemas específicos (DOMINGUEZ; BOELENS; BONVIN, 2003).

3.3 Visualização e análise estrutural dos dímeros e tetrâmeros

A visualização das estruturas ancoradas foi realizada via PyMol 1.8 (SCHRÖDINGER, [s.d.]). O mesmo foi utilizado para análises de resíduos de interação entre as estruturas ancoradas juntamente ao PDBsum (LASKOWSKI et al., 2018). As análises das estruturas com relação ao posicionamento das regiões N-terminal e C-terminal entre as proteínas na conformação dimérica e tetramérica foram feitas via PyMol 1.8 (SCHRÖDINGER, [s.d.]). Tais análises, em conjunto, buscam descrever quantitativamente e qualitativamente as interações físico-químicas entre os monômeros e determinar quais conformações demonstram compatibilidade com a associação na membrana celular, representando, possivelmente, a estrutura nativa do complexo. 


\section{RESULTADOS E DISCUSSÃO}

\subsection{Dímeros formados por docking molecular não-direcionado}

\subsubsection{ClusPro}

A partir do docking não-direcionado dos monômeros da porção extracelular da proteína CD38 humana (código PDB 1YH3) com o software ClusPro, verificou-se a formação de estruturas com características distintas de interação (Figuras 7 e 8). Dentre as estruturas, algumas são formadas prioritariamente por meio da interação entre as regiões N-terminal, enquanto outras interagem por meio de ambas as regiões ( $\mathrm{N}$-terminal e $\mathrm{C}$-terminal).

Nenhuma das estruturas geradas demonstrou compatibilidade com a associação na membrana, dispondo as regiões $\mathrm{N}$-terminais em direção a uma mesma região. A estrutura melhor classificada é apresentada na figura 7, as duas seguintes estruturas, segundo a classificação dos complexos pelo ClusPro, são mostradas na figura 8.

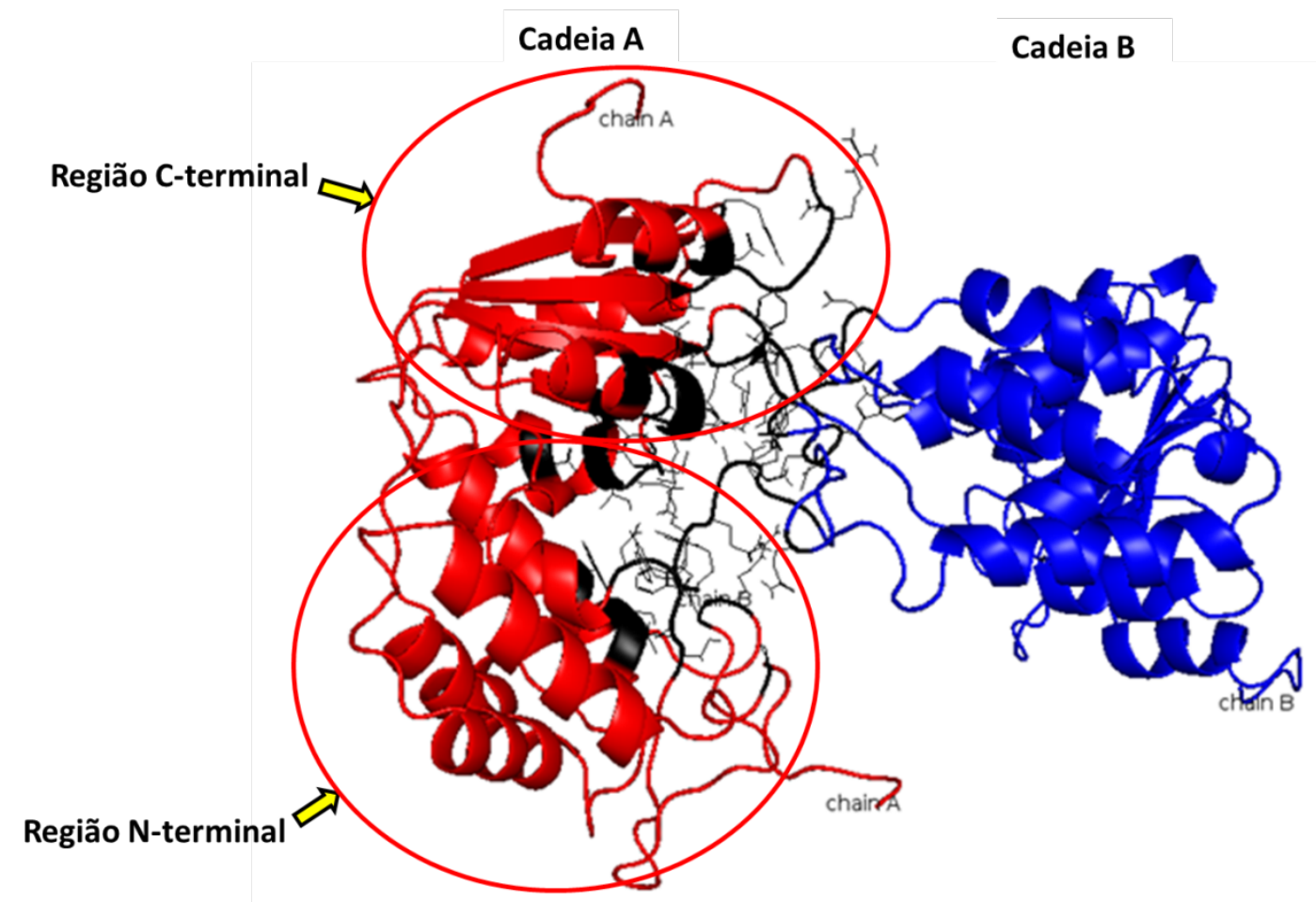

Figura 7. Estrutura melhor classificada do dímero de hCD38 (CD38 humana) criada por meio de docking nãodirecionado com o software ClusPro. Os monômeros são identificados por cores distintas (vermelho = cadeia A e azul = cadeia B). A região em preto marca os resíduos da interface de interação entre os monômeros na formação do homodímero da hCD38. Os círculos em vermelho indicam as regiões C e N-terminal da cadeia A. 

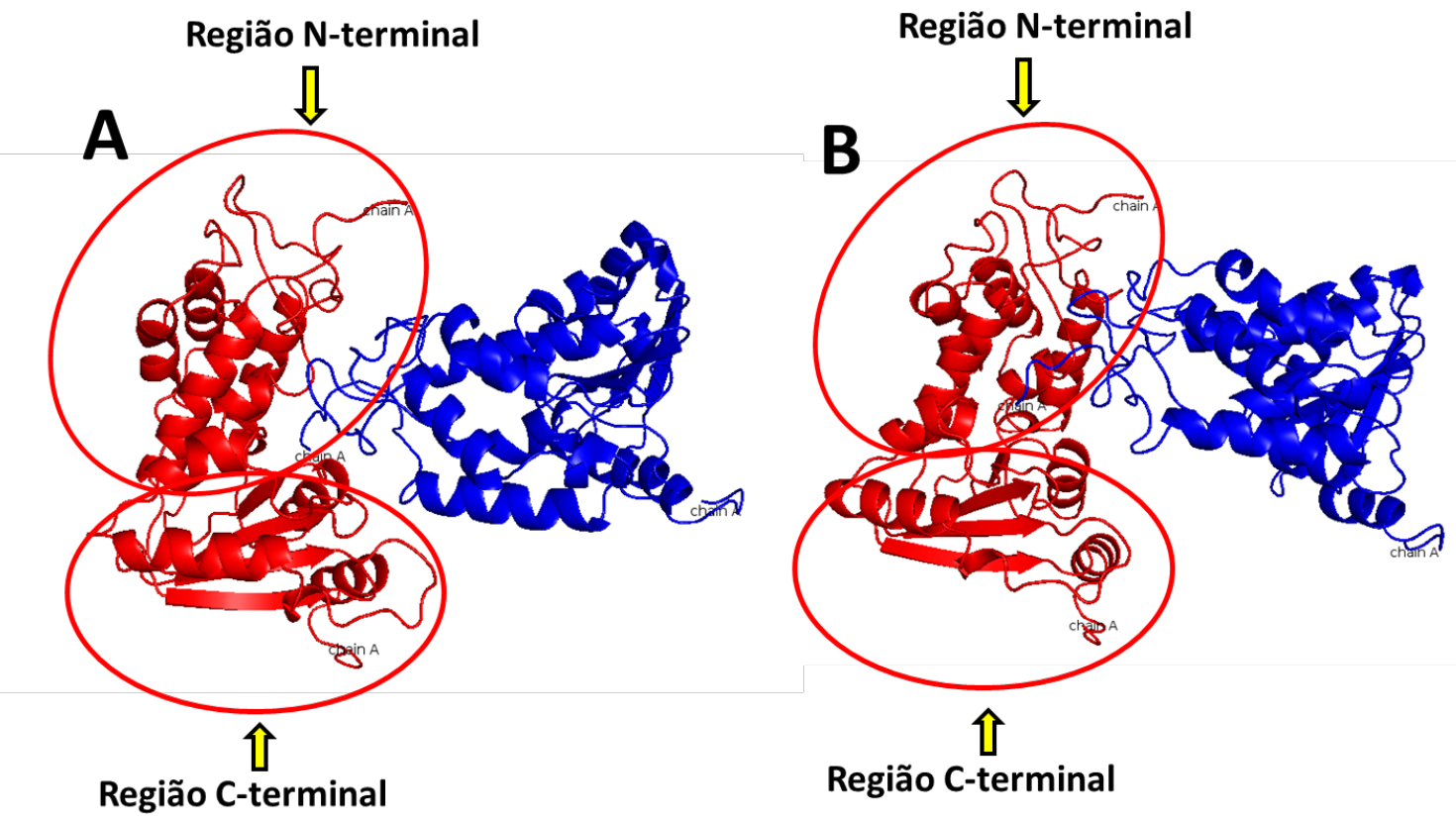

Figura 8. Estrutuas criadas por meio de docking não-direcionado com o software ClusPro. As 2 estruturas (A e $\mathrm{B})$ representam as classificadas em $2^{\circ}(\mathrm{A})$ e $3^{\circ}(\mathrm{B})$. Os monômeros são identificados por cores distintas em cada um dos dímeros (vermelho e azul). Os círculos em vermelho indicam as regiões $\mathrm{C}$ e $\mathrm{N}$-terminal da cadeia A de ambos os dímeros.

Em contraposição aos resultados de Hara-Yokoyama e col. (2012) que preveem a formação de dímeros da porção extracelular da CD38 humana, tomando como referência a CD38 de camundongo, por meio da interação das $\alpha$-hélices 1 de seus monômeros (Figura 9), os resultados do docking não-direcionado da porção extracelular da CD38 humana não demonstraram tal interação nas estruturas finais. Ainda, Hara-Yokoyama e col. (2012) propuseram que a formação de dímeros da CD38 seja facilitada pela interação de suas estruturas completas inseridas, por meio da região transmembranar, na membrana celular. 


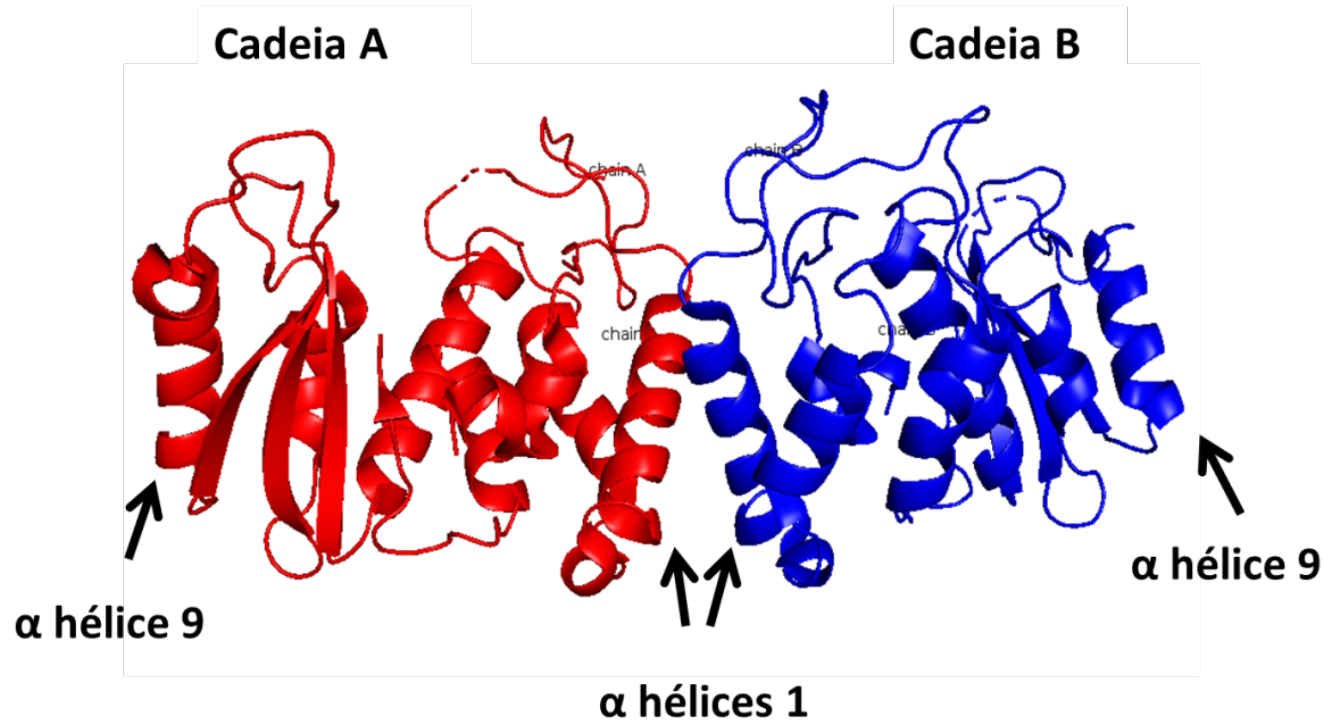

Figura 9. Cristal da proteína CD38 de camundongo (2eg9) com mutação nos sítios de glicosilação e o truncamento da $\alpha$ hélice 9 na região C-terminal da proteína. Nesta estrutura, a proteína apresenta dois monômeros interagindo por meio das $\alpha$ hélices 1 . As diferentes cadeias são identificadas por cores distintas, em vermelho (cadeia A) e em azul (cadeia B). Fonte: Adaptado de Hara-Yokoyama e col (2012).

Em Egea e col. (2012), formas mono-glicosiladas da CD38 bovina foram reveladas como homodímeros “costas com costas” (interação por meio de região oposta ao sítio catalítico) paralelos (Figura 10), o que não seria permitido no caso da CD38 de camundongo devido à glicosilação no resíduo N124. Quando considerados os homodímeros de Aplysia ciclase (Figura 11 A) e CD157, a estrutura se dispõe em homodímeros "cabeça com cabeça" (interação por meio das regiões C-terminal) e “cauda com cauda” (interação por meio das regiões N-terminais) (YAMAMOTO-KATAYAMA et al., 2002).

Assim, a montagem da CD38 pode ter diversidade entre as espécies, reforçando a necessidade de estudos experimentais e in silico comparativos entre as diversas formas da proteína CD38 e seus complexos. 


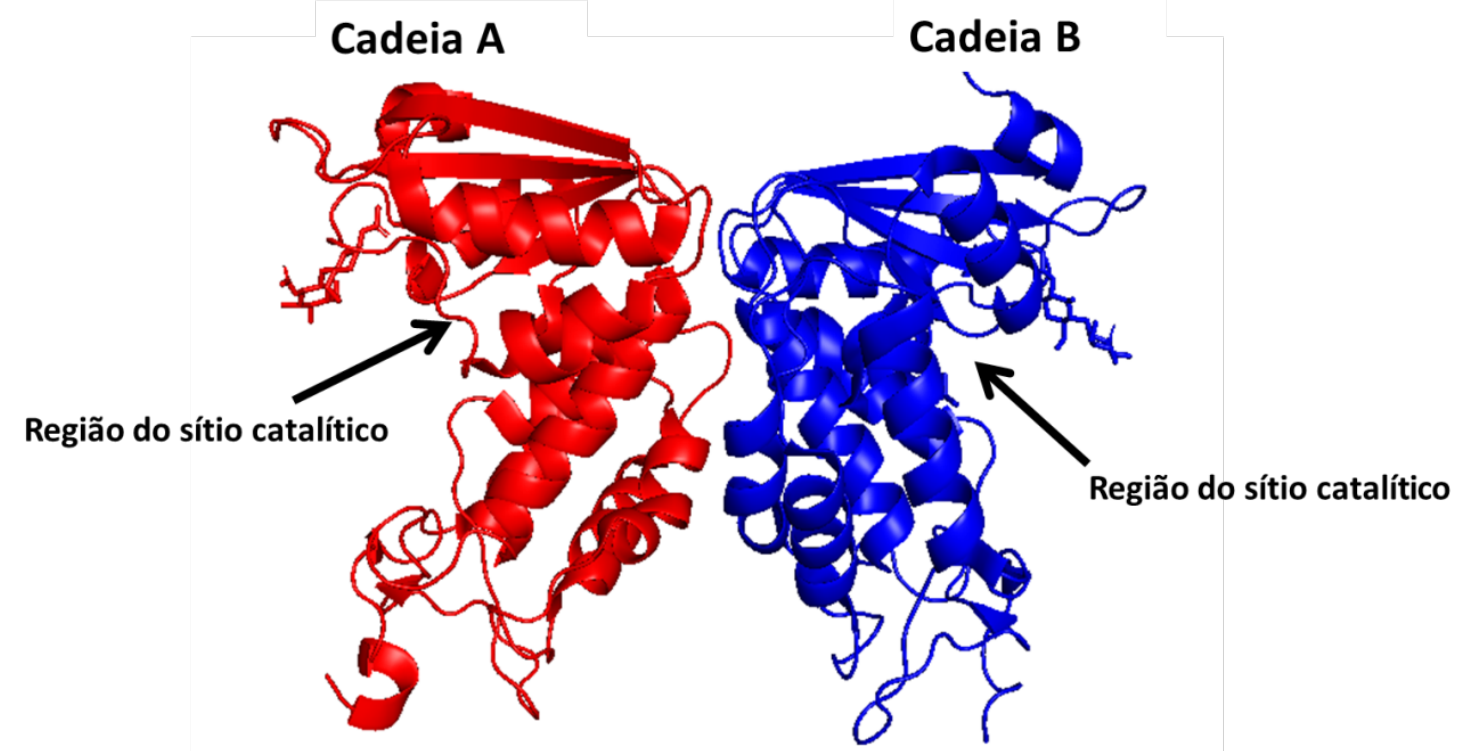

Figura 10. Dímero de CD38 bovina apresentando interação por meio de região oposta ao sítio catalítico (setas em cor preta). As cadeias são diferenciadas por cores distintas em vermelho (cadeia A) e azul (cadeia B).

Por meio do cristal da shCD38 (CD38 humana solúvel) (LIU et al., 2005), juntamente com dados experimentais (BRUZZONE et al., 1998, MORENO-GARCIA et al., 2004), HaraYokoyama e col. (2012) deduziram que na ausência do domínio transmembranar e da cauda intracelular, a shCD38 pode não formar um dímero funcional em solução ou em cristais. As associações intermoleculares laterais observadas (EGEA et al., 2012; HARA-YOKOYAMA et al., 2012; SHI et al., 2006; PRASAD et al., 1996) podem ser artefatos formados pela força de empacotamento cristalográfico ou por agregação molecular.

Além da estrutura da porção extracelular da proteína CD38 de camundongo (2EG9) (HARA-YOKOYAMA et al., 2012) (Figura 9), um cristal de Aplysia ADP-ribosyl cyclase (1LBE) (PRASAD et al., 1996) apresenta dímeros interagindo por meio das $\alpha$ hélices 1 dos monômeros (Figura 11 A). Uma forma de interação semelhante foi relatada por Shi e col. (2006) na estrutura do domínio extracelular da CD38 humana (1ZVM) (SHI et al., 2006) (Figura 11 B). Esses dados, em conjunto com informações experimentais, de mutações na $\alpha$ hélice 1 que desagregam estruturas diméricas da proteína CD38 (MORENO-GARCÍA et al., 2004) foram relevantes para a utilização do direcionamento desta $\alpha$ hélice no docking direcionado com o software HADDOCK 2.2 no presente trabalho. 


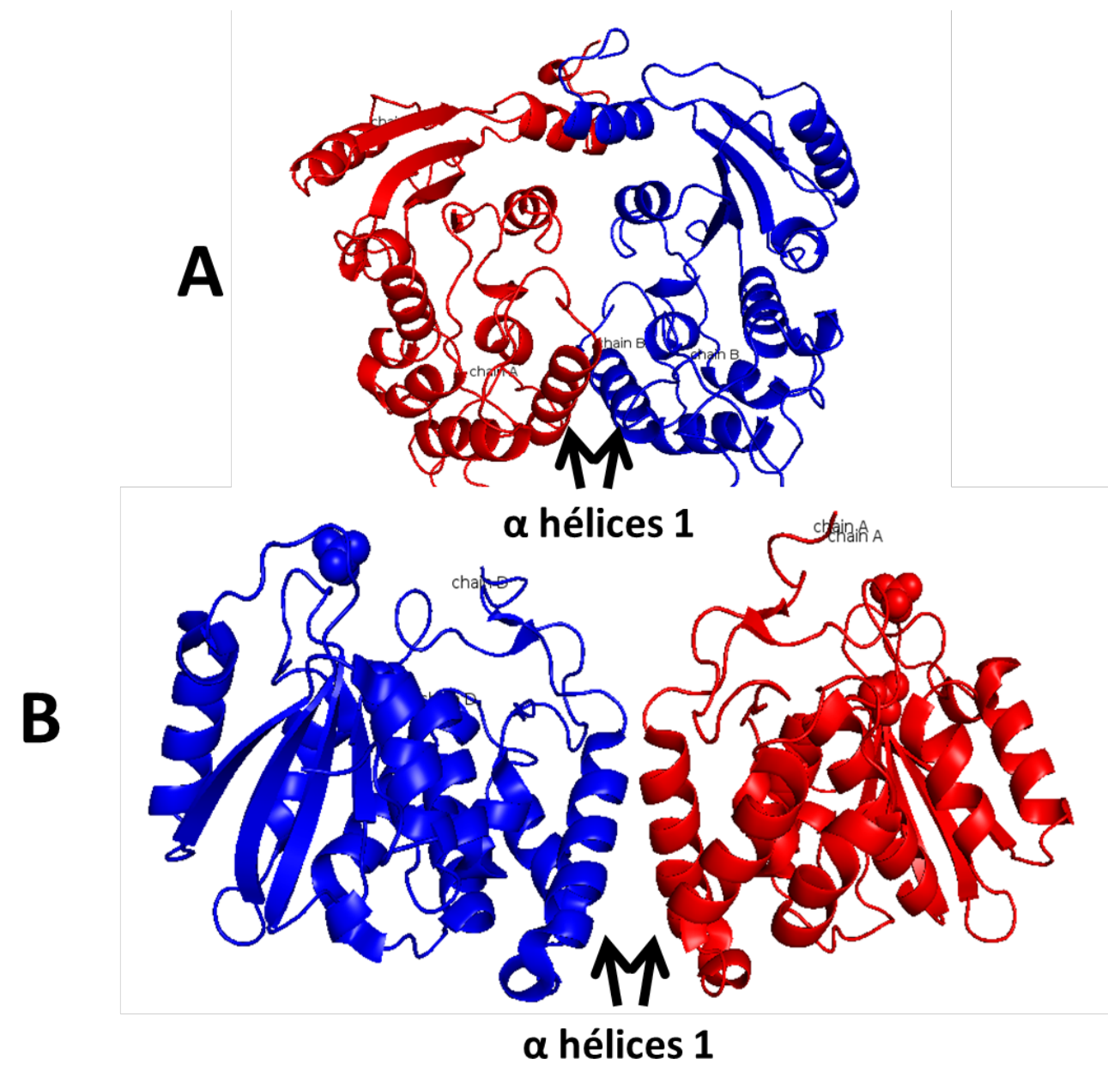

Figura 11. Em A é apresentada a estrutura da Aplysia ADP-ribosyl cyclase (1LBE). Em B é apresentada a estrutura do domínio extracelular da CD38 humana (1ZVM), ambas estruturas mostrando interação entre monômeros via $\alpha$ hélice 1. Fonte: Prasad et al., (1996) (1LBE) e Shi et al., (2006) (1ZVM).

4.2 Dímeros formados por docking molecular direcionado

\subsubsection{HADDOCK 2.2}

O direcionamento da região da $\alpha$ hélice 1 , como região ativa no docking molecular da hCD38 com HADDOCK 2.2, demonstrou a possibilidade da formação dos dímeros por meio desse modo de interação. Dentre os modelos gerados, o modelo melhor classificado, evidenciado por meio da avaliação de parâmetros energético e sumarizado num HADDOCK score (tabela 2), apresentou compatibilidade de associação na membrana por ambos os 
monômeros direcionarem as regiões $\mathrm{N}$-terminal para o mesmo local que, na proteína completa inserida na membrana, seria a continuação de sua porção transmembranar (Figura 12).

Tabela 2. Parâmetros energéticos avaliados pelo HADDOCK do cluster 2, assim como o score (HADDOCK score) associado à estrutura energeticamente mais favorável entre os gerados pelo método.

\begin{tabular}{|l|r|}
\hline \multicolumn{2}{|c|}{ CLUSTER 2 } \\
\hline HADDOCK Score & $-84.9+/-2.4$ \\
\hline Cluster size & 17 \\
\hline $\begin{array}{l}\text { RMSD from the overall lowest- } \\
\text { energy structure }\end{array}$ & $3.2+/-1.2$ \\
\hline Van der Waals energy & $-23.1+/-5.1$ \\
\hline Electrostatic energy & $-262.3+/-16.1$ \\
\hline Desolvation energy & $-10.4+/-8.8$ \\
\hline Restraints violation energy & $9.8+/-10.18$ \\
\hline Buried Surface Area & $926.5+/-161.6$ \\
\hline Z-Score & -1.6 \\
\hline
\end{tabular}

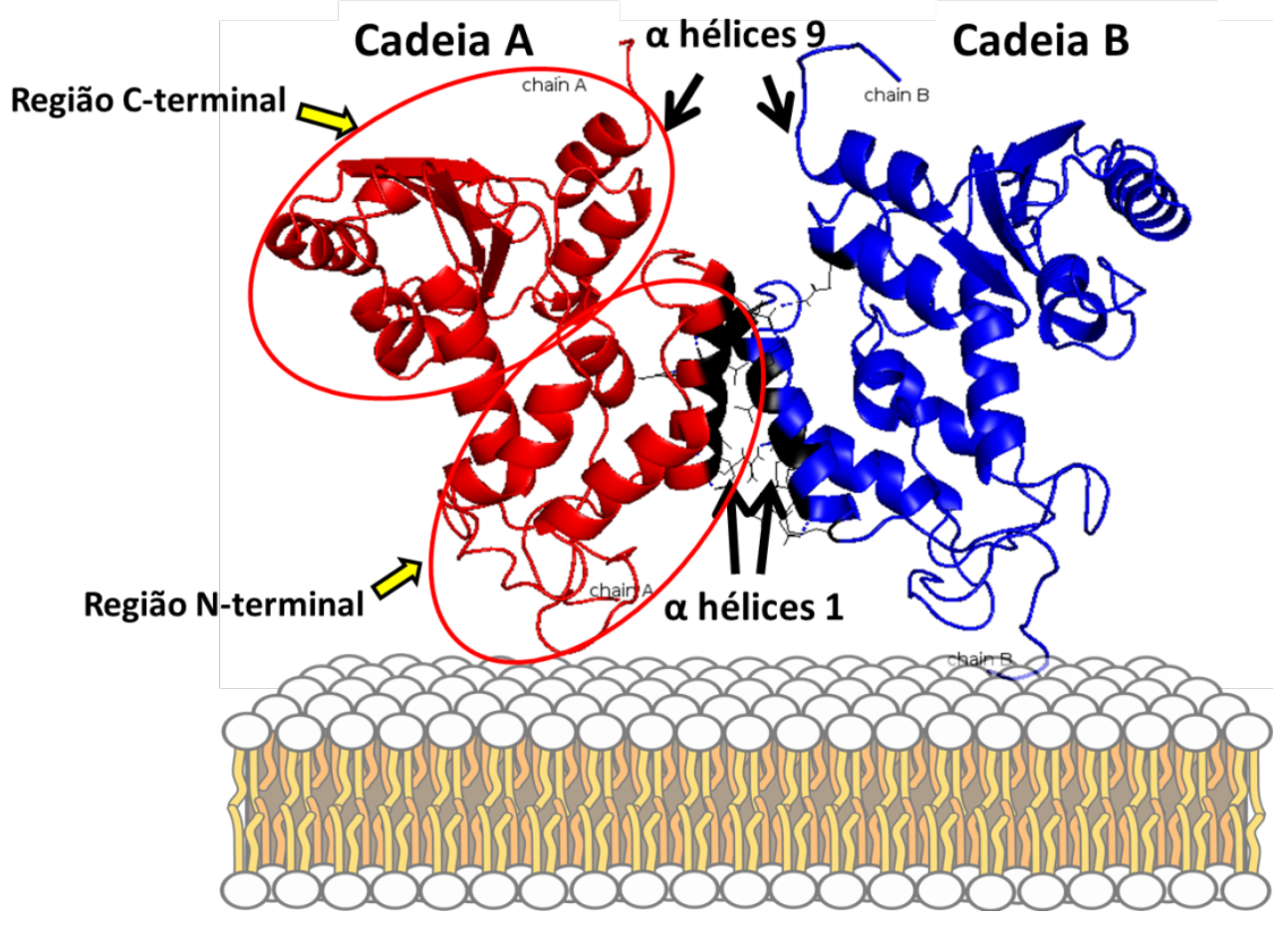

Figura 12. Estrutura classificada como energeticamente mais favorável entre as geradas pelo docking direcionado com HADDOCK 2.2 da hCD38. Na figura, os monômeros que formam os homodímeros são distinguidos por cores diferentes em vermelho (cadeia A) e em azul (cadeia B). Na região em preto estão representados os resíduos da interface de interação responsáveis pela estabilização do dímero. Na imagem, a ilustração de uma bicamada lipídica foi inserida para demonstrar o posicionamento do dímero em relação a uma membrana celular. As $\alpha$ hélices 1 e 9 são indicadas por setas em cor preta. Círculos vermelhos delimitam as regiões $\mathrm{N}$ e C-terminal da cadeia A. 
Para caracterizar a interface de interação entre os monômeros e identificar os resíduos de aminoácidos de importância na formação do dímero, foi utilizado o servidor PDBsum (LASKOWSKI et al., 2018) que realiza diversas análises da estrutura proteica, assim como do complexo disponibilizado ao servidor (Figura 13). Na figura 13, o número de linhas de ligação de hidrogênio (linhas azuis) entre dois resíduos indica o número de ligações potenciais desta natureza entre eles. Para contatos não ligados como interações hidrofóbicas (linhas tracejadas), que podem ser abundantes, a largura da linha é proporcional ao número de contatos atômicos. Ainda, na imagen, os resíduos de aminoácidos são coloridos de acordo com suas características físico-químicas em vermelho (carga negativa), azul (carga positiva), verde (neutro), cinza (alifático) e laranja (prolina ou glicina). Nos círculos dessas imagens, cadeias de interação são unidas por linhas coloridas, cada uma representando um tipo diferente de interação como as pontes salinas (vermelho), pontes dissulfeto (amarelo), ligação de hidrogênio (azul) interações hidrofóbicas (laranja).
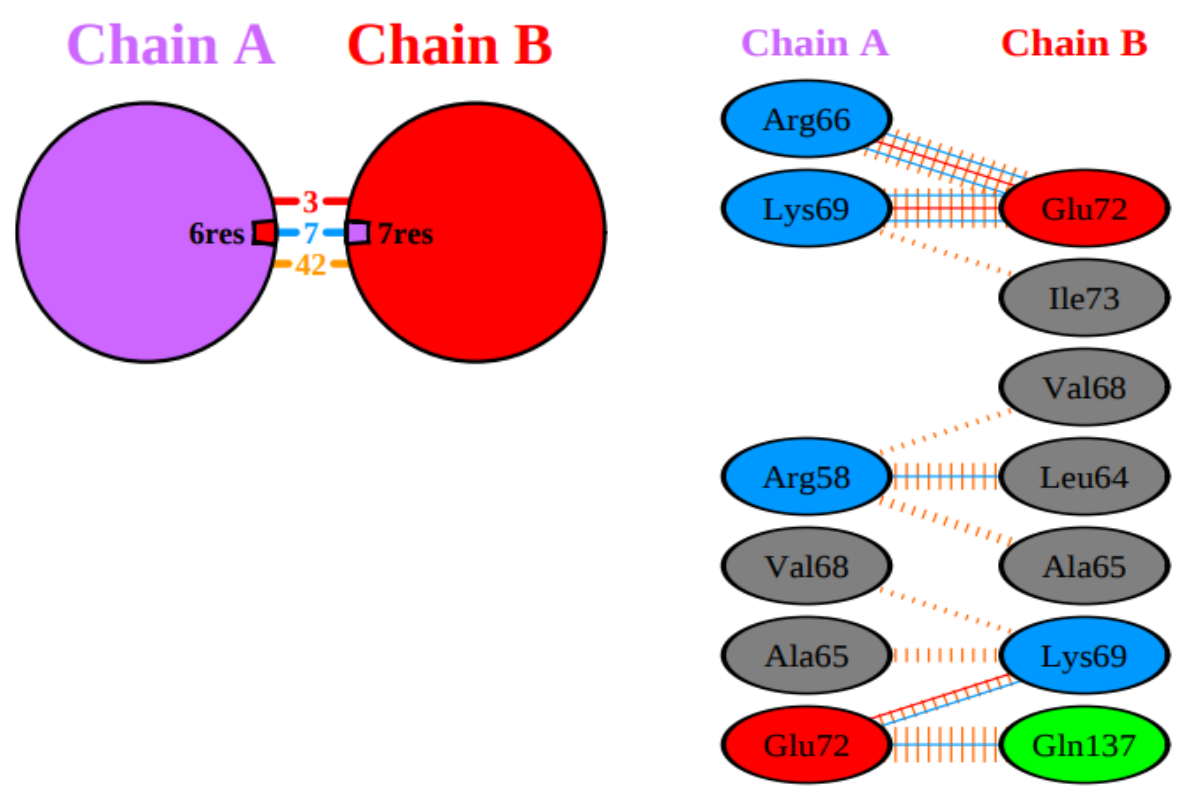

Figura 13. Caracterização da interface de interação entre os monômeros da hCD38 na formação do dímero. Na imagem é mostrado um resumo da quantidade de resíduos e os tipos de interação (hidrofílicas e hidrofóbicas) responsáveis pela estabilização do homodímero. Nesta, estão descritos quais resíduos encontram-se na interface de interação e suas características físico-químicas. Os resíduos de aminoácidos são coloridos de acordo com suas características fisico-químicas: em vermelho (carga negativa), azul (carga positiva), verde (neutro), cinza (alifático) e laranja (prolina ou glicina). Ligações de hidrogênio (linhas azuis) e interações hidrofóbicas (linhas tracejadas) são mostradas entre os resíduos. Nos círculos dessas imagens, cadeias de interação são unidas por linhas coloridas, cada uma representando um tipo diferente de interação como as pontes salinas (vermelho), pontes dissulfeto (amarelo), ligação de hidrogênio (azul) e interações hidrofóbicas (laranja). 
4.2.1.1 Cristal de mCD38 (2EG9) e resíduos de interação

Hara-Yokoyama e col. (2012) propuseram a estrutura de dímeros e tetrâmeros da hCD38 utilizando a estrutura da proteína mCD38 (2EG9) com mutação nos sítios de glicosilação e o truncamento da $\alpha$ hélice 9 em sua região C-terminal. A similaridade de sequência e estrutura entre mCD38 e hCD38 possibilita, segundo os autores, a comparação dos resultados e transferência da hipótese das regiões de interação encontradas no cristal de mCD38 para a hCD38. A proposta envolve a existência de três diferentes regiões de interação entre os monômeros na formação do dímero (forma de interação do tipo I) e tetrâmero (formas de interação dos tipos II e III) da proteína (Figura 14). Na estrutura, criada por cristalografia de raio X e com resolução de 2.8Â, o truncamento na região C-terminal da mCD38 tem, por consequência, a perda da $\alpha$ hélice 9, que se mostra completamente desordenada, e a flutuação da $\alpha$ hélice 4 (HARA-YOKOYAMA et al., 2012).

No estrutura da mCD38 (2EG9), a $\alpha$ hélice 1 existe na interface do tipo I, identificada como principal responsável na formação dos dímeros da CD38. Nessa interface, interações hidrofílicas (D64-R69 / R69-D64 e Q75-Q75) e 45 interações hidrofóbicas (entre estas, D67I72 / I72-D67 e L71-L71) são formadas (HARA-YOKOYAMA et al., 2012) como representado na figura 15, em análise feita por meio do servidor PDBsum. Comparada ao dímero formado com HADDOCK 2.2, no presente trabalho, no qual são formadas 7 interações hidrofílicas (R66-E72 / R58-L64 / E72-K69) e 42 hidrofóbicas (Figura 13), as $\alpha$ hélices 1 das CD38 (hCD38 e mCD38) apresentam diferenças na sequência de resíduos de aminoácidos, porém, em sua maioria, mantendo as características físico-químicas, como é o caso do resíduo 69 que em mCD38 apresenta uma arginina (Arg69 - positivo) e em hCD38 apresenta uma lisina (Lys69 - positivo), sendo responsável pela formação de uma das ligações de hidrogênio entre os monômeros. 


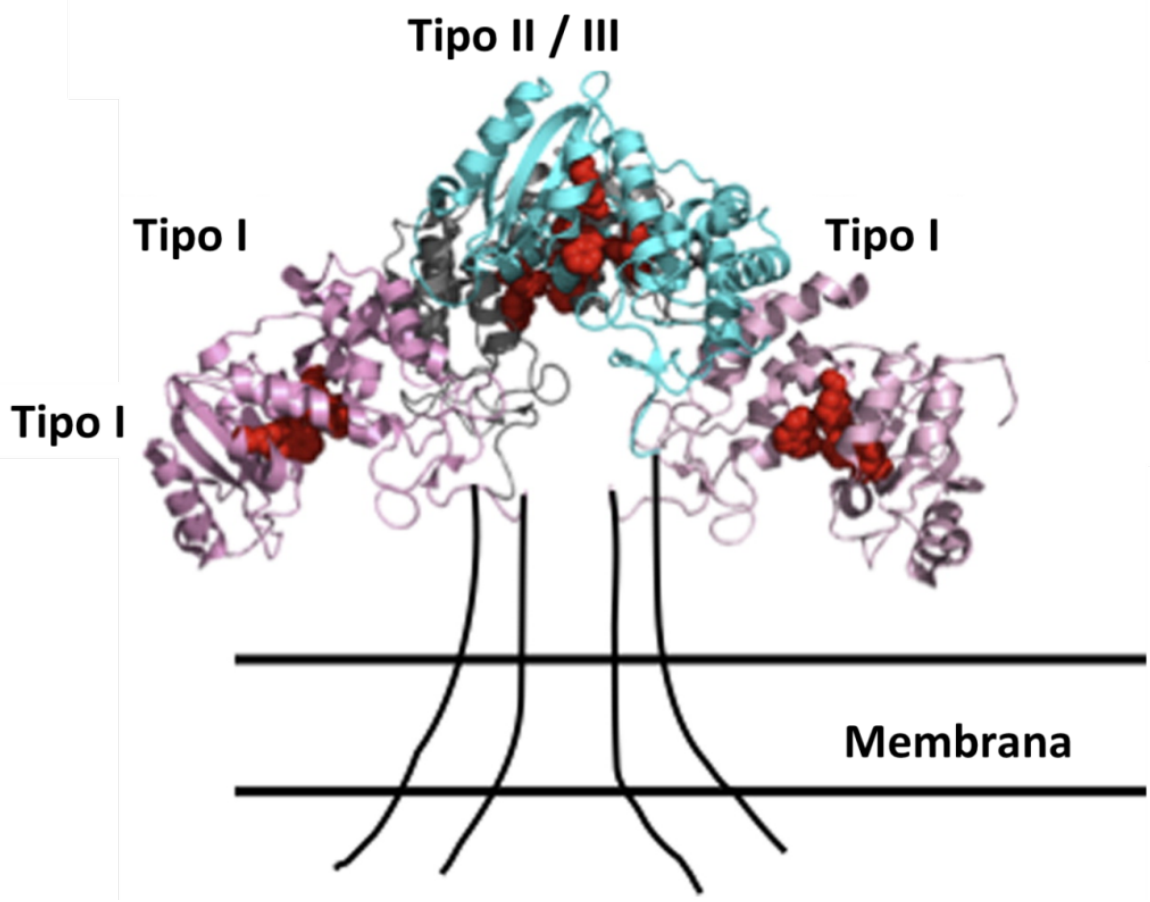

Figura 14. Proposta envolvendo a existência de três diferentes regiões de interação entre os monômeros na formação do dímero (forma de interação do tipo I) e tetrâmero (formas de interação dos tipos II e III) da proteína CD38 humana. Fonte: Adaptado de Hara-Yokoyama (2012).
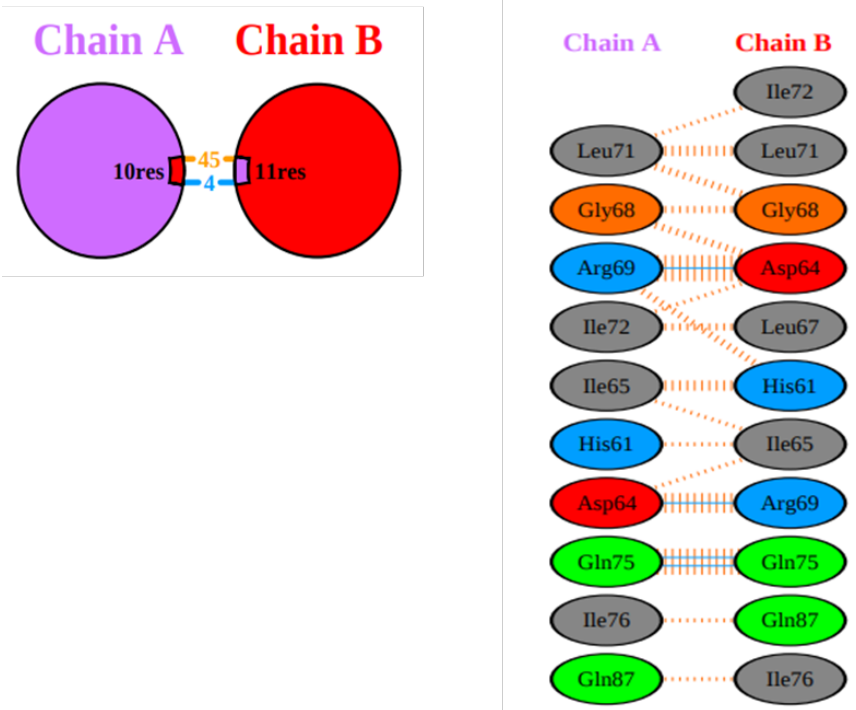

Figura 15. Caracterização da interface de interação entre os monômeros da mCD38 no cristal 2eg9. Na imagem é mostrado um resumo da quantidade de resíduos e os tipos de interação responsáveis pela estabilização do homodímero. Nesta, são descritos quais resíduos encontram-se na interface de interação e suas características físico-químicas. Os resíduos de aminoácidos são coloridos de acordo com suas características fisico-químicas: em vermelho (carga negativa), azul (carga positiva), verde (neutro), cinza (alifático) e laranja (prolina ou glicina). Ligações de hidrogênio (linhas azuis) e interações hidrofóbicas (linhas tracejadas) são mostradas entre os resíduos. Nos círculos dessas imagens, cadeias de interação são unidas por linhas coloridas, cada uma representando um tipo diferente de interação como as pontes salinas (vermelho), pontes dissulfeto (amarelo), ligação de hidrogênio (azul) e interações hidrofóbicas (laranja). 
4.2.1.2 Evidências experimentais da formação de dímeros por meio das $\alpha$ hélices 1 da proteína CD38

Nos dados de Moreno-García e col. (2004), a análise de mutantes CD38, expressos em células $\mathrm{Ba} / \mathrm{F}$, revelou que o truncamento da região citoplasmática ou a mutação de um único aminoácido na $\alpha$ hélice 1, G68E, de mCD38 diminuiu a estabilidade dos homodímeros da proteína quando solubilizados em detergente. As células que expressam os homodímeros CD38 instáveis tiveram uma expressão diminuída desta proteína na membrana plasmática e as meia-vidas destas proteínas mutantes na membrana plasmática foram significativamente reduzidas. Esses resultados demonstram a importância das regiões citoplasmáticas e da $\alpha$ hélice 1 na manutenção estrutural do dímero e dinâmica celular de proteína CD38.

Em Moreno-García e col. (2004), o tratamento da proteína mCD38 de comprimento total na superfície celular de linfócitos B por crosslinking com a molécula BS3, uma molécula impermeável à membrana que interage com resíduos de lisina, converteu a proteína em dímeros que foram desestabilizados pela mutação G68E (resíduo presente na $\alpha$ hélice 1).

Em Hara-Yokoyama e col. (2012), o mesmo tratamento, porém utilizando o domínio extracelular isolado de mCD38, a converteu em um dímero ligado covalentemente. Posteriormente, utilizando o mesmo dímero, foi analisado se a ligação cruzada dos dímeros com BS3 ocorre por meio da interação entre as $\alpha$ hélices 1 . Se assim fosse, o candidato para o sítio interligado seriam os resíduos Lys60-Lys60, presentes nesta região. No entanto, a digestão enzimática posterior do dímero com tripsina, gerou resíduos de Lys60 detectáveis quando os fragmentos do dímero interligado foram analisados por espectroscopia de massa e, caso todos os dímeros interligassem por meio das lisinas na $\alpha$ hélice 1 , seria esperado que esses resíduos não sofressem clivagem.

Assim, levando em consideração os dados de crosslinking dos dímeros da CD38 solúveis e os dados de clivagem por tripsina, é improvável que a ligação cruzada dependente de BS3, no caso destes dímeros, tenham ocorrido todas por meio do modo de interação que envolve as $\alpha$ hélices 1 dos monômeros (HARA-YOKOYAMA et al., 2012). Tais resultados corroboram os obtidos no docking não-direcionado com o ClusPro (Figuras 7 e 8), nos quais a porção extracelular isolada, e com ampla possibilidade de movimentação, pôde interagir de maneiras distintas, gerando dímeros que interagem numa diversidade de formas.

A proteína CD38 é encontrada na superfície celular interagindo com diversos complexos proteicos que variam dependendo do tipo de célula envolvida (QUARONA et al., 2013). Em Hara-Yokoyama e col. (2008), a proteína mCD38, reconhecida por encontrar-se 
em regiões especializadas na membrana celular, como as balsas lipídicas, foi recuperada em DRMs (membranas resistentes a detergentes) (BROWN AND ROSE, 1992) após as células da linhagem A20, que a expressam, terem sido lisadas. As quantidades da CD38 nos DRMs foram reduzidas pela ocorrência da mutação G68E na $\alpha$ hélice 1 e pelo truncamento da $\alpha$ hélice 9, demonstrando a importância da interação entre os monômeros por meio da hélice $\alpha$ 1, que é desestabilizada pela mutação, e da região da $\alpha$ hélice 9 para a associação da proteína nas regiões especializadas da membrana.

Em células A20, a mutação G68E aboliu completamente a atividade de glicohidrolase da CD38, efeito comparável com a mutação do resíduo cataliticamente importante Glu150 para Leu (E150L) (MORENO-GARCIA et al., 2004). Considerando que a mutação G68E desestabiliza a interação homofílica, que ocorre entre as $\alpha$ hélices 1 da CD38, o resultado sugere que a integridade da interação é necessária para a atividade catalítica da proteína na superfície celular (HARA-YOKOYAMA et al., 2012).

Em resumo, a formação de dímeros da proteína CD38 demonstrou que, quando não são especificadas regiões de interação entre os monômeros, estes possuem ampla possibilidade de movimentação, o que também é verificado em estudos experimentais (HARA-YOKOYAMA et al., 2012) com a proteína solúvel. Nesses casos, regiões diferentes podem ser responsáveis pela formação homodimérica da CD38. Porém, a compatibilidade de associação de ambos os monômeros na membrana celular é crucial para função da CD38 (MORENO-GARCÍA et al., 2004) e tal compatibilidade apenas foi identificada em dímeros formados pelo docking molecular direcionando resíduos da alfa hélice 1 da proteína.

Em conjunto, os dados de docking molecular do presente trabalho corroboram as informações da literatura (BRUZZONE et al., 1998; HARA-YOKOYAMA et al., 2012; MORENO-GARCÍA et al., 2004), ao indicar a importância da alfa hélice 1 na formação de dímeros da CD38. Assim, também corrobora a possibilidade de interações variáveis, quando há ampla possibilidade de movimentação dos monômeros, como acontece no docking nãodirecionado e nos dímeros da proteína solúvel.

\subsection{Tetrâmeros formados por docking não-direcionado}

Para realizar o docking não-direcionado na formação de tetrâmeros, foi utilizado o dímero obtido com o docking direcionado com HADDOCK 2.2 para testar se dímeros interagindo por meio das $\alpha$ hélices 1 poderiam, sem direcionamento, formar estrutura tetramérica compatível com a associação na membrana celular. 


\subsubsection{ClusPro}

Nos modelos gerados pelo docking não-direcionado com o software ClusPro na formação de tetrâmeros, foi observada a prevalência de estruturas interagindo por meio das alças da região N-terminal da proteína hCD38, como representado na figura 16. Esta região possui resíduos de aminoácidos com características predominantemente hidrofóbicas e, na proteína completa, precede a porção que interage com a membrana celular, também hidrofóbica. Na ausência da porção transmembranar da hCD38, as alças da região N-terminal dos monômeros interagem entre si ou com outras regiões da proteína. Em adição, nenhum dos modelos de tetrâmero formado possibilita a inserção, em conjunto, dos monômeros na membrana celular, tornando a combinação das interfaces incompatível com a associação na membrana.

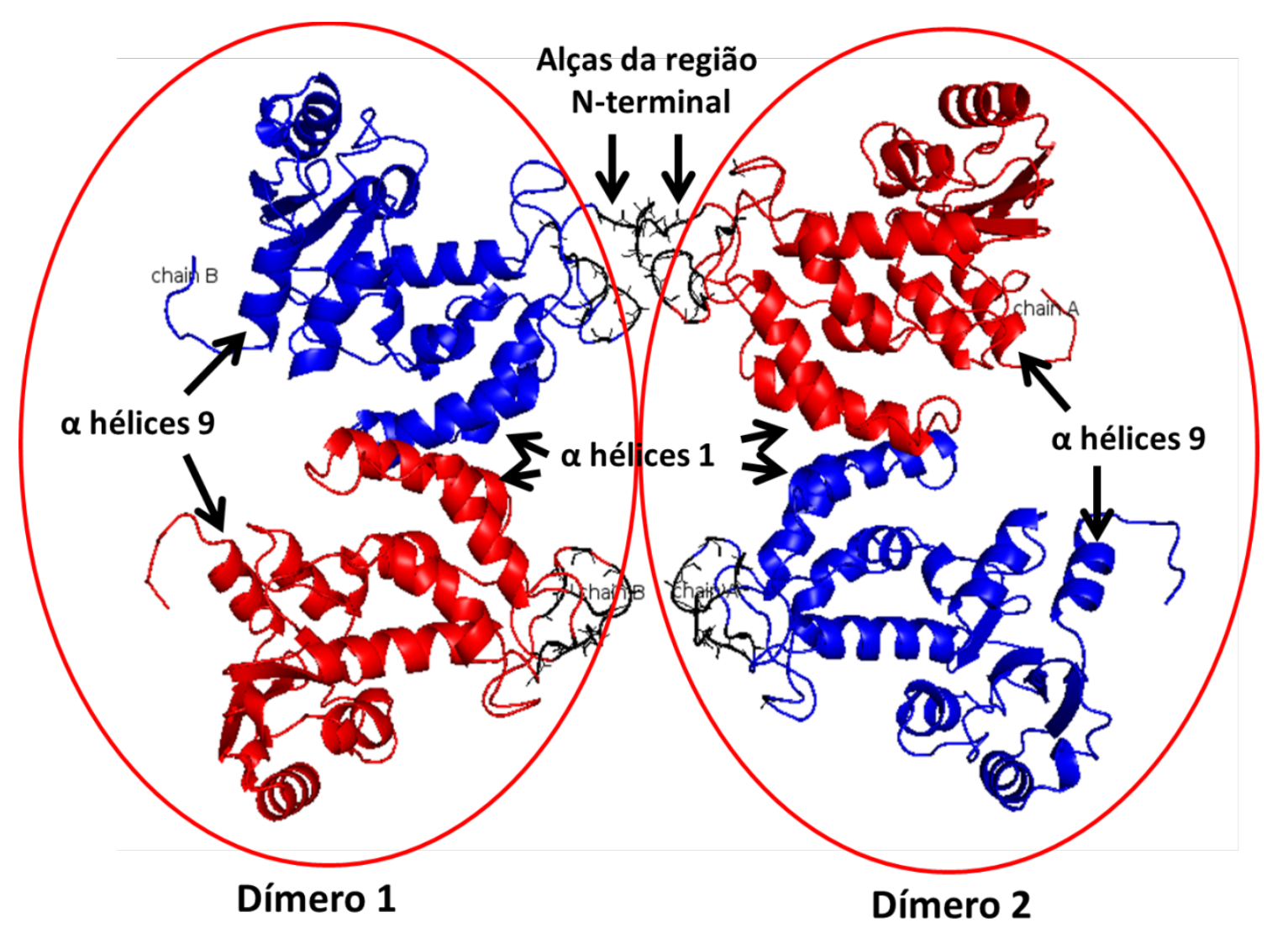

Figura 16. Estruturas geradas pelo docking não-direcionado dos dímeros HADDOCK como o software ClusPro. O modelo representa a estrutura melhor classificada. As regiões responsáveis pela estabilização da estrutura são representadas em preto. Na figura, os quatro monômeros que formam o tetrâmero estão representados por cores vermelha e azul. Os círculos em vermelho indicam os diferentes dímeros. 
4.4 Tetrâmeros formados por docking direcionado

\subsubsection{HADDOCK 2.2}

Na determinação dos resíduos ativos para o docking direcionado na formação do tetrâmero de hCD38 com o software HADDOCK 2.2, foram levadas em consideração as informações experimentais disponíveis na literatura (BRUZZONE et al., 1998, MORENOGARCIA et al., 2004, LIU et al., 2005, HARA-YOKOYAMA et al. 2012) que, em conjunto, demonstram a importância das regiões da $\alpha$ hélice 2 , $\alpha$ hélice 4, $\alpha$ hélice 9 e uma região de alça entre a cadeia $\beta 5$ e a $\alpha$ hélice 8 na formação do tetrâmero da proteína.

Como os dados indicam que os tetrâmeros são formados pela dimerização dos dímeros da CD38, inicialmente, para o processo de docking, foram especificados de forma alternada entre os monômeros os resíduos das regiões consideradas importantes e ativos na interação tetramérica ( $\alpha$ hélice 2, 4, 9 e alça entre cadeia $\beta 5$ e $\alpha$ hélice 8).

Buscando verificar a participação de cada dímero na tetramerização, foi realizado o docking de acordo com os dados especificados na tabela 3.

Tabela 3. Regiões e resíduos definidos como ativos no direcionamento para o primeiro docking direcionado com HADDOCK.

\begin{tabular}{|c|c|c|}
\hline & \multicolumn{2}{|r|}{ DÍMERO 1} \\
\hline & Região & Resíduos \\
\hline Cadeia A & $\alpha$ hélice 2 & DCQSVWDAFKG (resíduos 81 a 91) \\
\hline \multirow[t]{4}{*}{ Cadeia B } & $\alpha$ hélices 4,9 e alça & IKDLAHQFTQV (resíduos 128 a 138) \\
\hline & & RPDKFLQCVKNPE (resíduos 280 a 292) \\
\hline & & R (resíduo 247) \\
\hline & \multicolumn{2}{|r|}{ DÍMERO 2} \\
\hline Cadeia D & $\alpha$ hélice 2 & DCQSVWDAFKG (resíduos 81 a 91) \\
\hline \multirow[t]{3}{*}{ Cadeia C } & $\alpha$ hélices 4,9 e alça & IKDLAHQFTQV (resíduos 128 a 138) \\
\hline & & RPDKFLQCVKNPE (resíduos 280 a 292) \\
\hline & & R (resíduo 247) \\
\hline
\end{tabular}

Como resultado do primeiro docking direcionado com HADDOCK 2.2, foram geradas estruturas que, em sua maioria, demonstram incompatibilidade com a associação na membrana celular, porém a terceira estrutura melhor classificada por seu perfil energético (tabela 4) demonstrou a possibilidade de tal associação (Figura 17). Na estrutura, apenas um 
dos monômeros de cada dímero apresentou interações que envolveram as $\alpha$ hélices 4, 9 e região de alça de ambos os monômeros (Figura 18).

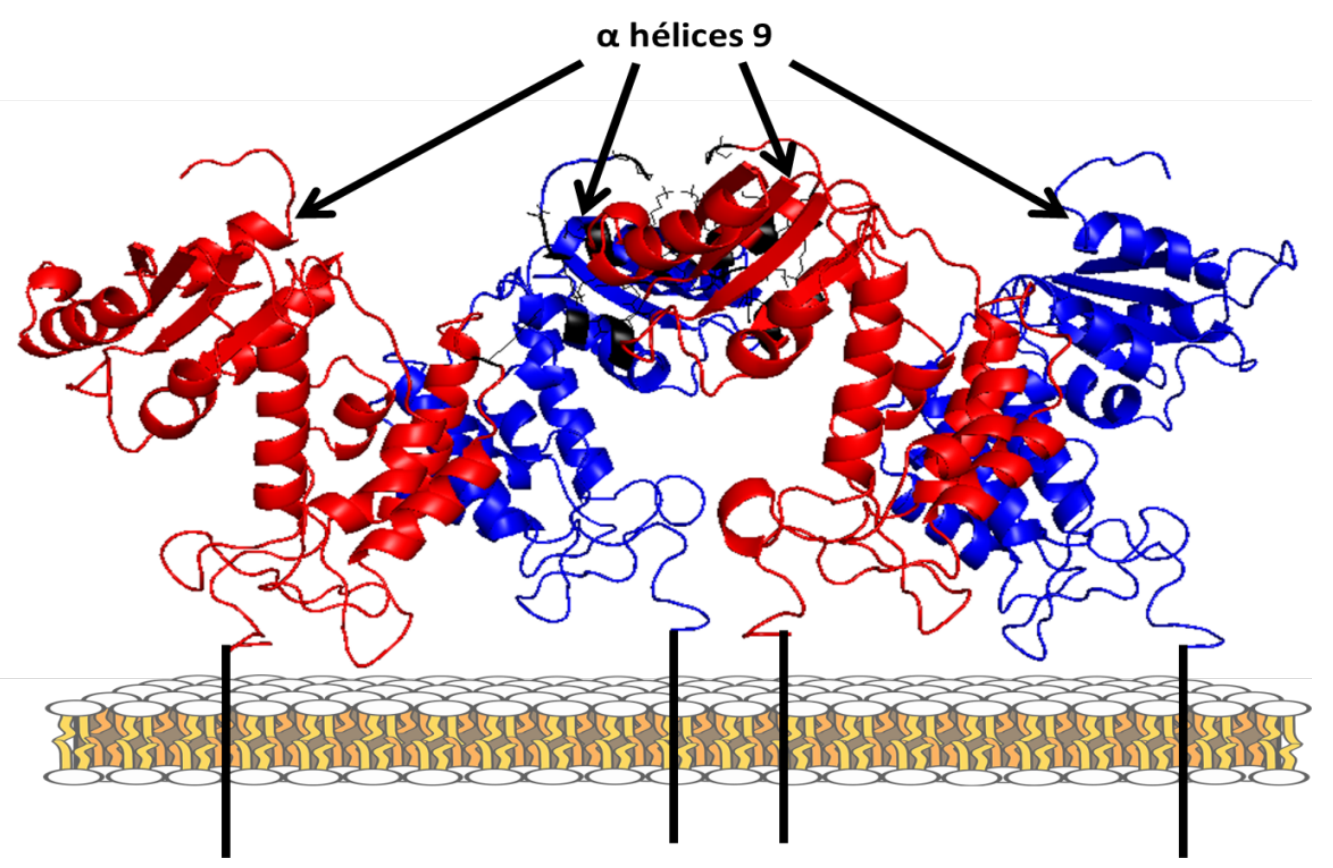

Figura 17. Tetrâmero formado por meio de docking direcionado com o software HADDOCK2.2. A estrutura apresenta compatibilidade de associação com a membrana celular ao posicionar as regiões $\mathrm{N}$-terminal de cada monômero em direção à membrana. Na figura, a ilustração de uma bicamada lipídica é apresentada. As regiões das $\alpha$ hélices 9 dos monômeros estão indicadas por setas em cor preta.

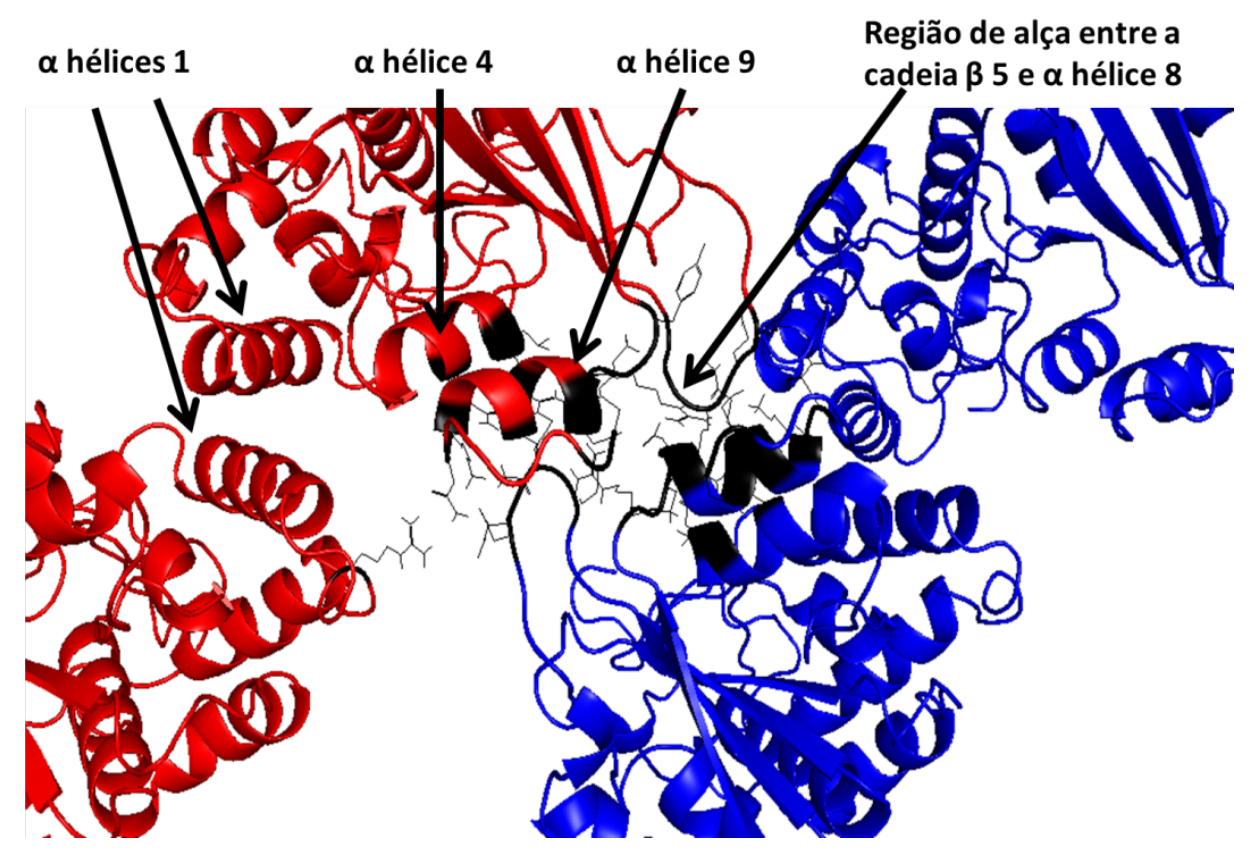

Figura 18. Interface de interação (região em preto) entre os resíduos responsáveis pela estabilização do tetrâmero de hCD38. Participam da interface os resíduos das $\alpha$ hélices 4 e 9 e da região de alça entre a cadeia $\beta$ 5 e $\alpha$ hélice 8 em ambos os dímeros. 
Tabela 4. Tabela apresentando os parâmetros energéticos avaliados pelo HADDOCK do cluster 1, assim como o score (HADDOCK score) da estrutura avaliada como a terceira na classificação.

\begin{tabular}{|l|r|}
\hline \multicolumn{2}{|c|}{ CLUSTER 1 } \\
\hline HADDOCK Score & $-30+/-11.2$ \\
\hline Cluster size & 32 \\
\hline $\begin{array}{l}\text { RMSD from the overall lowest- } \\
\text { energy structure }\end{array}$ & $27.0+/-0.6$ \\
\hline Van der Waals energy & $-72.9+/-4.5$ \\
\hline Electrostatic energy & $-323.0+/-55.9$ \\
\hline Desolvation energy & $56.4+/-7.2$ \\
\hline Restraints violation energy & $510.1+/-53.26$ \\
\hline Buried Surface Area & $2066.6+/-58.8$ \\
\hline Z-Score & -1.7 \\
\hline
\end{tabular}

O docking seguinte foi realizado buscando testar uma maior contribuição de cada um dos monômeros que formam os dímeros. Diferente do primeiro docking, todas as regiões indicadas como de importância na estabilização do tetrâmero ( $\alpha$ hélice 2, 4, 9 e alça entre cadeia $\beta 5$ e $\alpha$ hélice 8) foram marcadas como ativas em cada monômero.

Tabela 5. Regiões e resíduos definidos como ativos no direcionamento para o segundo docking direcionado com HADDOCK.

\begin{tabular}{|c|c|c|}
\hline & \multicolumn{2}{|r|}{ DÍMERO 1} \\
\hline & Região & Resíduos \\
\hline \multirow[t]{4}{*}{ Cadeia A } & $\alpha$ hélices 2, 4, 9 e alça & DCQSVWDAFKG (resíduos 81 a 91) \\
\hline & & IKDLAHQFTQV (resíduos 128 a 138) \\
\hline & & RPDKFLQCVKNPE (resíduos 280 a 292) \\
\hline & & $\begin{array}{l}\text { R (resíduo 247) } \\
\end{array}$ \\
\hline \multirow[t]{5}{*}{ Cadeia B } & $\alpha$ hélices 2, 4, 9 e alça & DCQSVWDAFKG (resíduos 81 a 91) \\
\hline & & IKDLAHQFTQV (resíduos 128 a 138) \\
\hline & & RPDKFLQCVKNPE (resíduos 280 a 292) \\
\hline & & R (resíduo 247) \\
\hline & & DÍMERO 2 \\
\hline \multirow[t]{4}{*}{ Cadeia D } & $\alpha$ hélices 2, 4, 9 e alça & DCQSVWDAFKG (resíduos 81 a 91) \\
\hline & & IKDLAHQFTQV (resíduos 128 a 138) \\
\hline & & RPDKFLQCVKNPE (resíduos 280 a 292) \\
\hline & & \begin{tabular}{|c|} 
R (resíduo 247) \\
\end{tabular} \\
\hline \multirow[t]{4}{*}{ Cadeia C } & $\alpha$ hélices 2, 4, 9 e alça & DCQSVWDAFKG (resíduos 81 a 91) \\
\hline & & IKDLAHQFTQV (resíduos 128 a 138) \\
\hline & & RPDKFLQCVKNPE (resíduos 280 a 292) \\
\hline & & R (resíduo 247) \\
\hline
\end{tabular}


Como resultado do segundo docking, foram geradas estruturas tetraméricas compatíveis com a associação na membrana celular. A estrutura de maior favorecimento energético é mostrada na figura 19. As interfaces de interação responsáveis pela estabilização tetramérica estão apresentadas na figura 20. As energias associadas, juntamente ao HADDOCK score, da estrutura melhor classificada por suas características energéticas estão apresentadas na tabela 6. Cinco das estruturas de saída demonstraram ampla similaridade em suas interfaces de interação e estrutura geral, evidenciadas a partir de seus alinhamentos estruturais (Figura 21), indicando a importância das regiões ativas na interface para sua estabilização. A concordância entre cinco estruturas tetraméricas com ampla similaridade estrutural reforça a possibilidade da estrutura tetramérica de hCD38, criada por docking molecular direcionado, representar a estrutura nativa do tetrâmero na membrana celular.

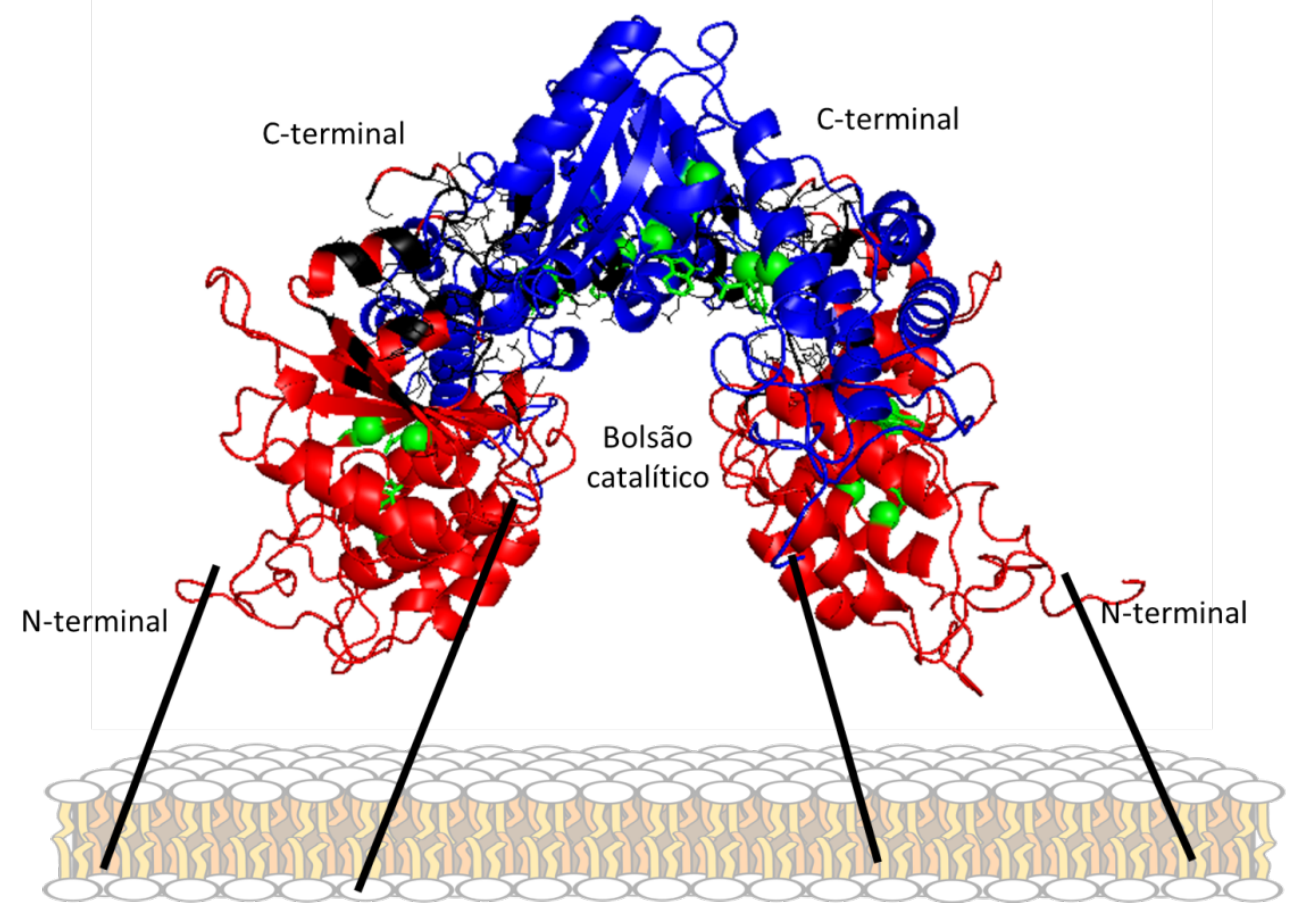

Figura 19. Estrutura de menor energia criada por meio de docking com software HADDOCK 2.2. Na estrutura, cada dímero é representado por dois monômeros (vermelho e azul). Em preto estão apresentadas as interfaces de interação responsáveis pela estabilização do complexo. Em verde estão destacados os resíduos de importância na função enzimática da proteína. Nota-se que o tetrâmero forma uma estrutura de bolsão entre os dímeros, região hipotética capaz de enclausurar moléculas que são catalisadas, como o NAD e NADP, e facilitar o influxo de seu produto para o interior celular. 
Tabela 6. Parâmetros avaliados pelo HADDOCK 2.2 da estrutura tetramérica melhor classificada por seu perfil energético.

\begin{tabular}{|l|r|}
\hline \multicolumn{2}{|c|}{ CLUSTER 3 } \\
\hline HADDOCK Score & $-50.1+/-12.6$ \\
\hline Cluster size & 14 \\
\hline $\begin{array}{l}\text { RMSD from the overall lowest- } \\
\text { energy structure }\end{array}$ & $1.4+/-0.8$ \\
\hline Van der Waals energy & $-108.8+/-15.4$ \\
\hline Electrostatic energy & $-757.2+/-64.1$ \\
\hline Desolvation energy & $80.3+/-10.5$ \\
\hline Restraints violation energy & $1298.1+/-155.04$ \\
\hline Buried Surface Area & $4065.6+/-194.1$ \\
\hline Z-Score & -2.1 \\
\hline
\end{tabular}

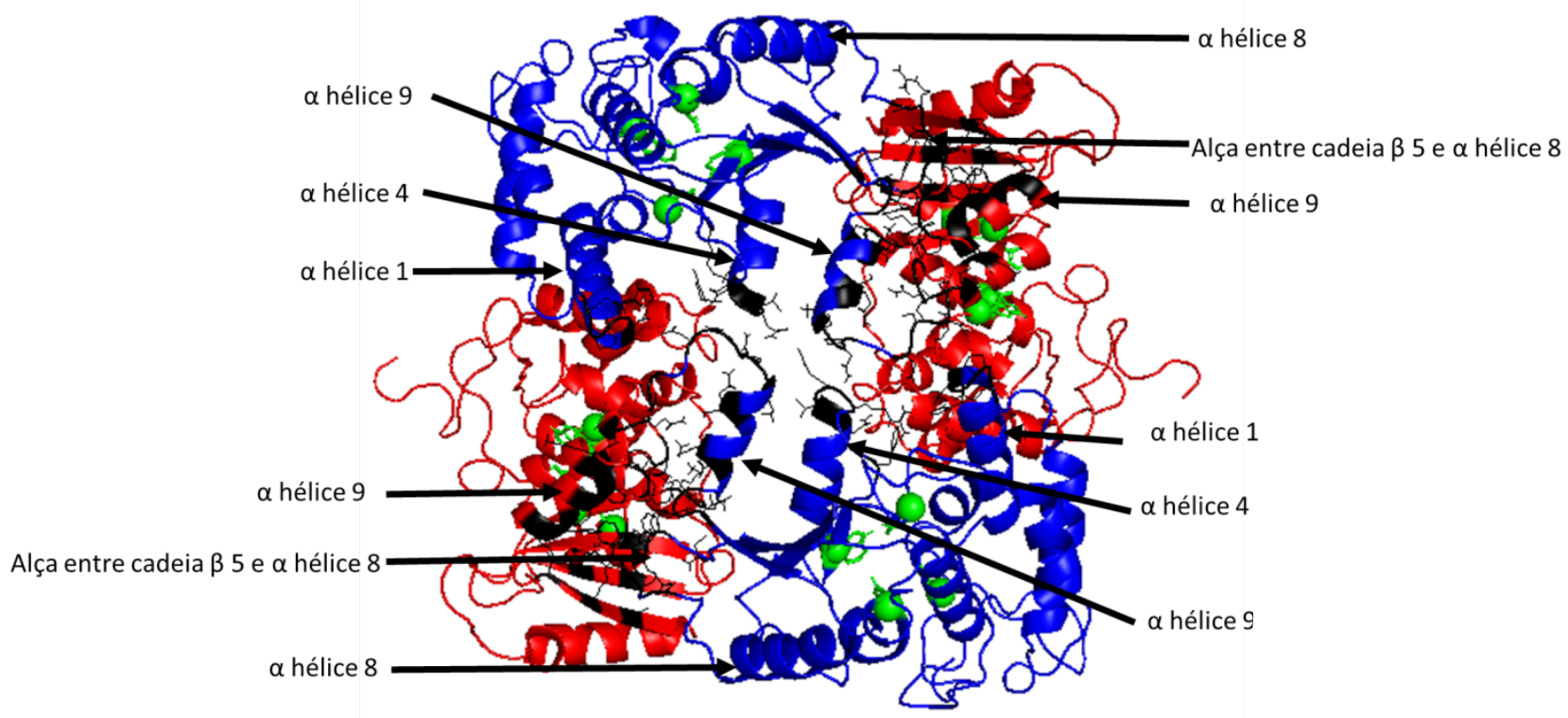

Figura 20. Estrutura de menor energia criada por meio de docking com software HADDOCK 2.2. Na figura estão representados os quatro monômeros que formam o tetrâmero da hCD38. Nesta esferas em verde representam os resíduos de aminoácidos importantes na atividade catalítica da enzima. Os resíduos de interação que estabilizam o tetrâmero estão em cor preta. As principais estruturas secundárias e alças responsáveis pela formação tetramérica estão indicadas por setas. 


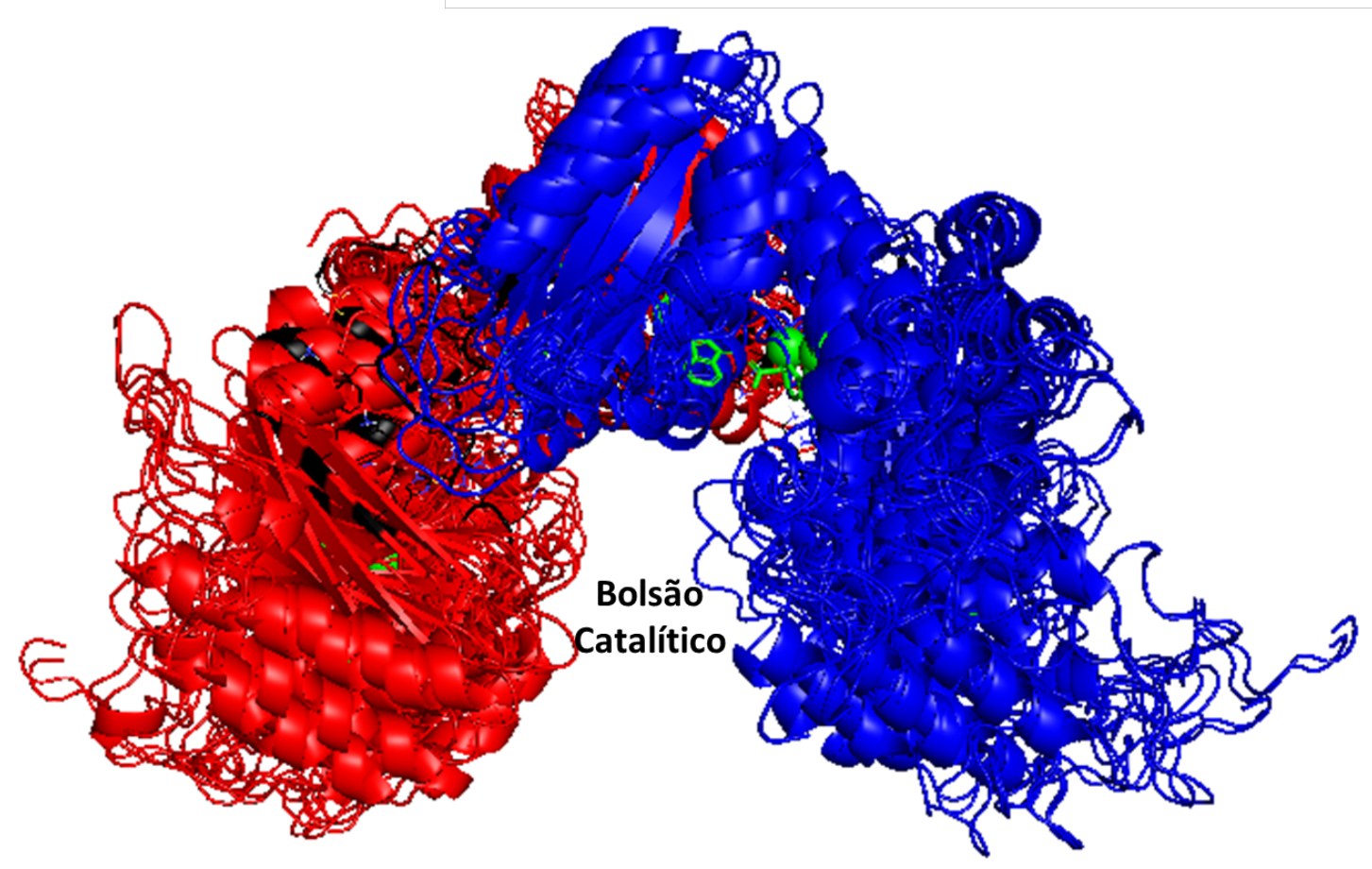

Figura 21. Alinhamento estrutural entre 5 estruturas tetraméricas geradas no segundo docking por meio do software HADDOCK 2.2. 
O perfil de interação entre os dímeros, assim como os resíduos da interface, das estruturas tetraméricas geradas no primeiro e segundo docking estão apresentados na figura 22, possibilitando sua comparação.
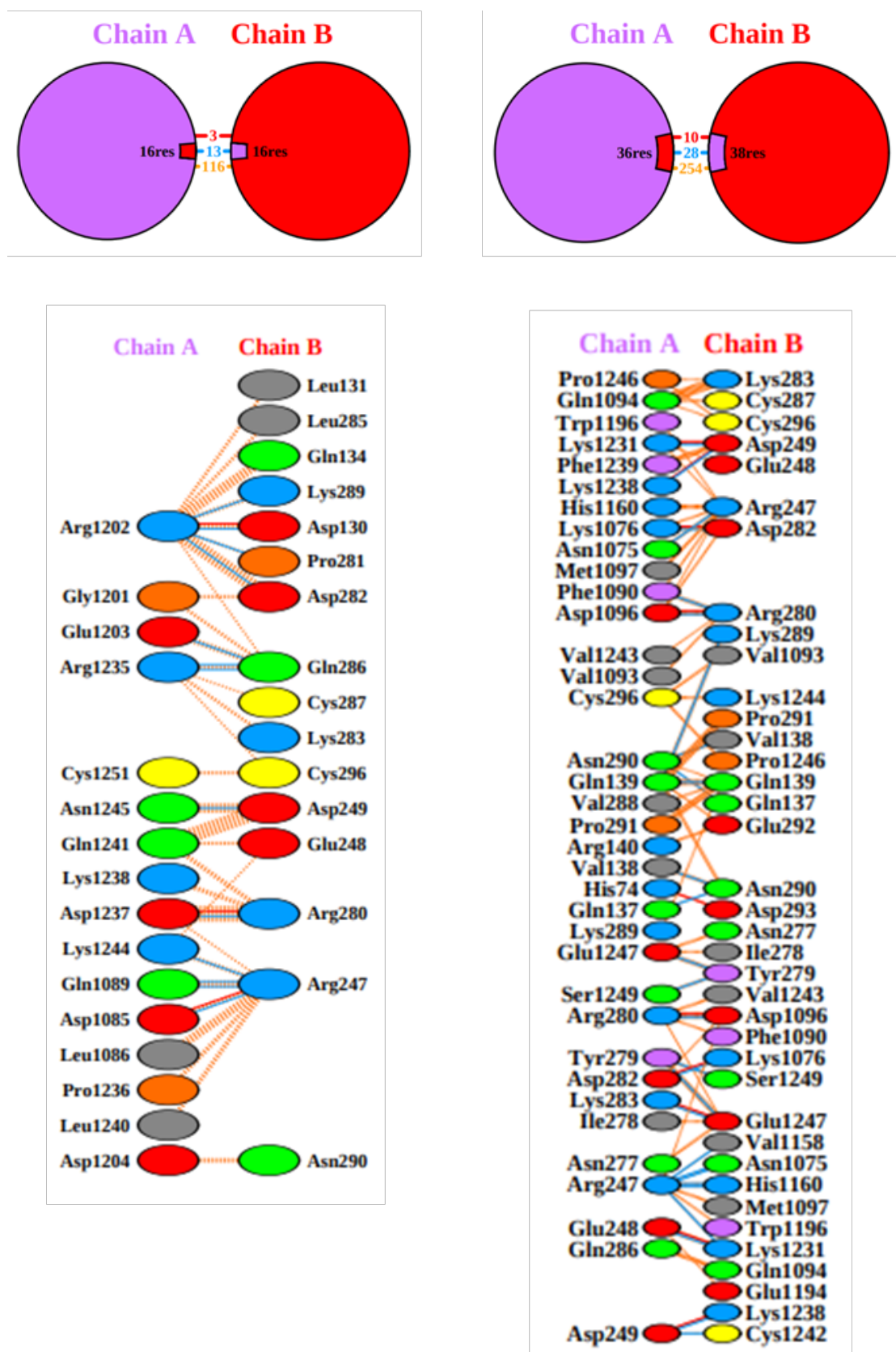

Figura 22. Perfil de interação entre os tetrâmeros e resíduos da interface responsáveis pela estabilização das estruturas tetraméricas geradas no primeiro (esquerda) e segundo (direita) docking. Os resíduos de aminoácidos são coloridos de acordo com suas características físico-químicas: em vermelho (carga negativa), azul (carga positiva), verde (neutro), cinza (alifático) e laranja (prolina ou glicina). Ligações de hidrogênio (linhas azuis) e interações hidrofóbicas (linhas tracejadas) são mostradas entre os resíduos. Nos círculos dessas imagens, cadeias de interação são unidas por linhas coloridas, cada uma representando um tipo diferente de interação como as pontes salinas (vermelho), pontes dissulfeto (amarelo), ligação de hidrogênio (azul) e interações hidrofóbicas (laranja). 
Por meio da comparação entre o perfil de interação e resíduos de interface dos tetrâmeros gerados no primeiro e segundo docking, é possível identificar no resultado do segundo docking um aumento na superfície de interação, demonstrado pela presença de ligações de hidrogênio, interações hidrofóbicas e pontes salinas. Nos parâmetros energéticos calculados pelo HADDOCK 2.2, esse aumento é caracterizado pela Área de Superfície Enterrada (do inglês Buried Surface Area - BSA), que mede o tamanho da interface em um complexo proteína-proteína (CHAKRAVARTY et al., 2013). O aumento das interações entre os dímeros pode indicar um aumento da estabilidade do segundo tetrâmero em relação ao primeiro e, assim, torná-lo a estrutura de maior viabilidade entre as geradas.

\subsubsection{Evidências da tetramerização}

Em Hara-Yokoyama e col. (2012), são propostas três formas de interação responsáveis pela estabilização do tetrâmero de mCD38 que, segundo os autores, podem ser válidas para hCD38 por sua similaridade em sequência e estrutural com mCD38. Na proposta, a interação do tipo I seria responsável por formar os dímeros, e esses dímeros, por meio das interações do tipo II e III, formariam os tetrâmeros da proteína.

No cristal utilizado para proposta, a $\alpha$ hélice 4 e 9 estão localizadas na interface do tipo III. A $\alpha$ hélice 2 está em contato com a região do laço entre a cadeia $\beta 5$ e a $\alpha$ hélice 8 na interface do tipo II. Embora a interface do tipo II, entre a $\alpha$ hélice 2 e a região da alça entre a cadeia $\beta 5$ e a $\alpha$ hélice 8 , por si só seja pequena demais para conectar duas moléculas de CD38, segundo o autor, ela pode contribuir para a oligomerização (HARA-YOKOYAMA et al., 2012) (Figura 23).

Utilizando dímeros do domínio extracelular isolado de mCD38 interligados com moléculas de BS3, Hara-Yokoyama e col (2012) detectaram que a clivagem por tripsina em resíduos da Lys145 da $\alpha$ hélice 4 foi diminuída, em relação ao padrão de clivagem esperado levando em consideração os monômeros separados, quando os fragmentos do dímero interligado foram analisados. Este resultado implica na interligação dependente de BS3 via modo de interação que envolve a região da $\alpha$ hélice 4 da proteína, resultado também demonstrado na estrutura da CD38 de camundongo (2eg9) (HARA-YOKOYAMA et al., 2012). Portanto, os dados indicam que os dímeros dos domínios extracelulares da CD38 podem existir em equilíbrio dinâmico formando um tetrâmero por meio da região proximal à $\alpha$ hélice 4 , dentro do qual ocorre o cruzamento intermolecular com BS3, evitando a digestão por tripsina neste local. 

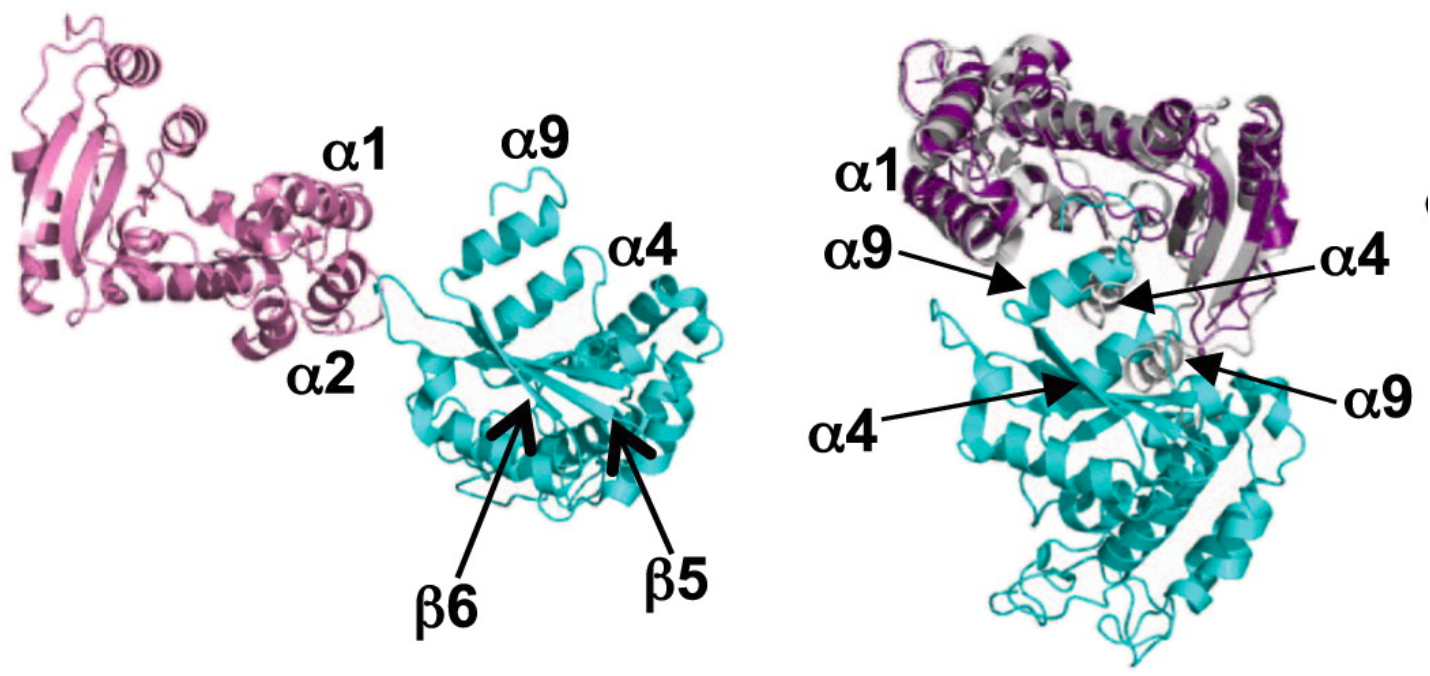

Figura 23. Interação entre as regiões da proteína mCD38 (2eg9). À esquerda a interação entre a $\alpha$ hélice 2 e a região de alça entre a cadeia $\beta 5$ e $\alpha$ hélice 8 (interação do tipo II). À direita é mostrada a interação entre as $\alpha$ hélices 4 e 9 de ambos os monômeros (interação do tipo III). Fonte: Hara-Yokoyama e col. (2012).

Em mCD38 é identificada a formação de ponte dissulfeto entre os resíduos de cisteína 291 e 300, presentes na $\alpha$ hélice 9 (LIU et al., 2005). Essa ponte dissulfeto é responsável pela estabilização da $\alpha$ hélice 9 e, em Hara-Yokoyama e col. (2012), o truncamento desta região afetou a atividade de NAD+ glicohidrolase. No mesmo trabalho, com a mutação dos resíduos 291 e 300 (C291A e C300A), foram observados dímeros de mCD38 ligados covalentemente mesmo na ausência da molécula BS3. Concebivelmente, as hélices da região C-terminal podem entrar em contato umas com as outras para permitir a formação de pontes dissulfeto intermoleculares artificiais entre Cys300-Cys300 e Cys291-Cys291 quando a ponte dissulfeto original é rompida e esses resíduos perdem seus parceiros intramoleculares. Estes resultados sugerem que a $\alpha$ hélice 9 C-terminal está envolvida na interação homofílica de mCD38 na membrana (HARA-YOKOYAMA et al., 2012).

Comparando os resultados experimentais aos do docking molecular, foi possível confirmar, in silico, a importância da $\alpha$ hélice 9 na interação homofílica responsável pela estabilização tetramérica de hCD38. Em ambas as estruturas tetraméricas resultantes do primeiro e segundo docking, a interação entre as $\alpha$ hélices 9 da região C-terminal demonstrou ser energeticamente favorável e, no segundo docking, as regiões de todos os monômeros interagiram de modo a manter o tetrâmero compatível com sua associação na membrana. 


\subsubsection{Estrutura do sítio ativo da CD38 e bolsão catalítico}

Entre os representantes da família das ADP-ribosil ciclases, os resíduos de importância catalítica estão localizados em posições equivalentes (LIU et al., 2005). Na estrutura da CD38 de camundongo com o truncamento na $\alpha$ hélice 9 (HARA-YOKOYAMA et al., 2012) foi identificada uma modificação dos resíduos W129 e E230, que correspondem aos resíduos W125 e E226 no domínio extracelular de hCD38. Quando analisadas as atividades catalíticas do domínio extracelular truncado, é identificada uma diminuição da atividade de glicohidrolase de $\mathrm{NAD}+$, indicando a importância da região C-terminal, onde se localiza a $\alpha$ hélice 9, na manutenção da estrutura da região catalítica da proteína e, consequentemente, em sua função catalítica.

Na estrutura do tetrâmero proposta por Hara-Yokoyama e col (2012), todos os locais catalíticos estão voltados para o espaço entre a proteína mCD38 e a superfície da membrana, porém no docking direcionado de dímeros formados pela interação entre as $\alpha$ hélices 1 de ambos os monômeros de hCD38 no presente trabalho, a estrutura não corresponde exatamente ao proposto. Nesta, apenas um dos monômeros em cada dímero mantêm seu sítio catalítico na região do bolsão formado na estrutura tetramérica, com o segundo monômero tendo seu sítio catalítico voltado à região externa do canal (Figura 24).

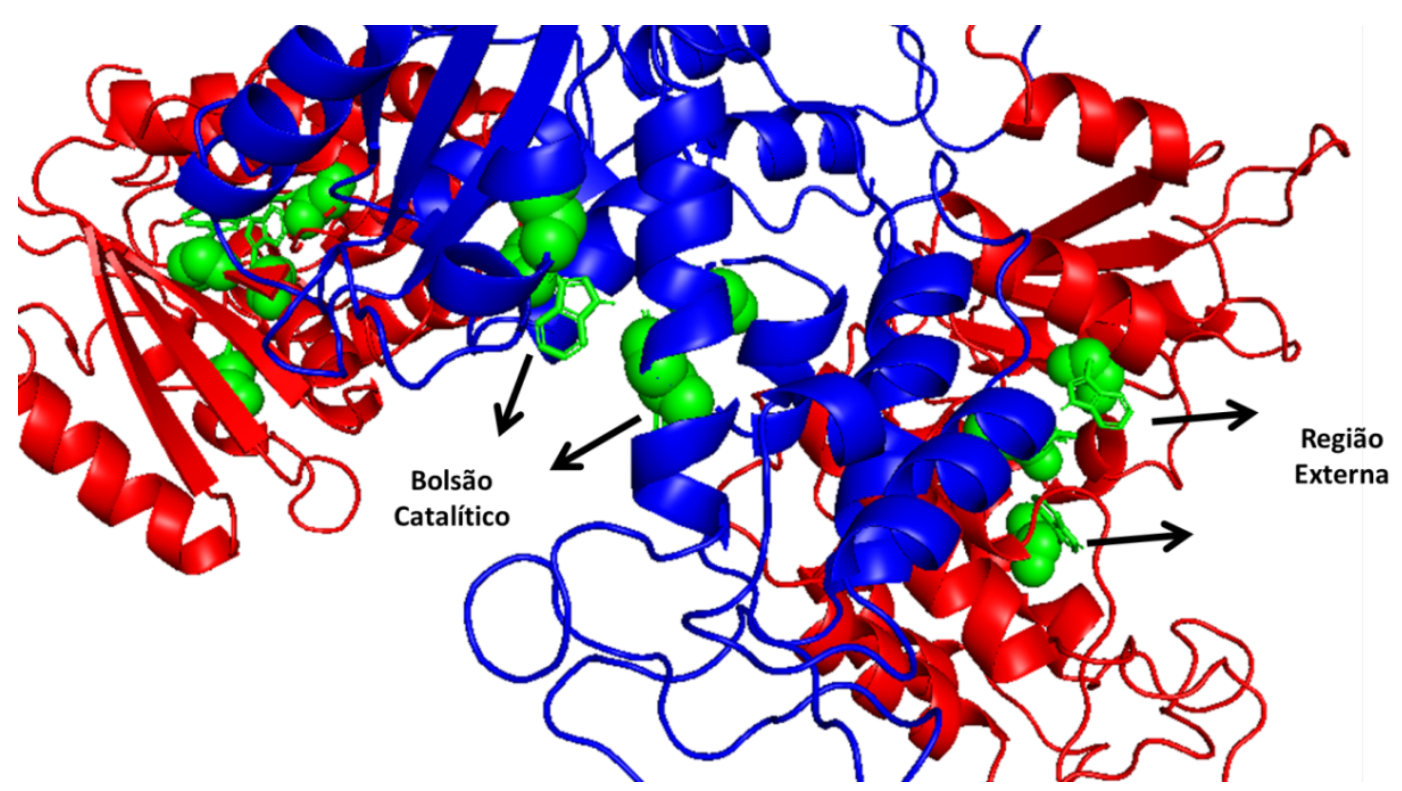

Figura 24. Parte do tetrâmero formado por meio do docking direcionado com HADDOCK 2.2. Os resíduos de importância catalítica estão apresentados em verde. Cada dímero é formado por monômeros de diferentes cores (azul e vermelho). Na imagem é possível identificar, no dímero em destaque, que os resíduos catalíticos de um dos monômeros estão voltados para o canal formado pela estrutura tetramérica. 
A estrutura gerada no segundo docking (Figuras 19 e 20), demonstra a formação de um bolsão entre os dois dímeros. Tal região também está presente na proposta de Hara-Yokoyama e col. (2012) ao analisar o cristal de mCD38. A formação de um bolsão é considerada fundamental para o influxo do produto da reação enzimática da proteína CD38, assim como a justaposição dos monômeros na organização deste canal (BRUZZONE et al., 1998). A CD38 oligomerizada pode atuar como um canal de ADP ribose cíclico (cADPR), formado por sua ação enzimática (FRANCO et al., 1998).

Em resumo, a segunda estrutura gerada pelo método de docking molecular direcionado demonstra concordância com as informações bioquímicas sobre: a possibilidade de formação de dímeros e tetrâmeros da proteína hCD38 energeticamente favoráveis; a importância das regiões de $\alpha$ hélices 1,2 , 4 e 9, assim como a alça entre a cadeia $\beta 5$ e $\alpha$ hélice 8 em sua estabilização; a formação de estrutura tetramérica dinâmica, formada por interações eletrostáticas, capaz de manter a associação com a membrana; formar um bolsão responsável pelo influxo de seu produto enzimático, por gradiente de concentração, para o interior celular e dispor parte de seus sítios catalíticos no interior deste bolsão. 


\section{CONCLUSÃO}

- O docking direcionado, utilizando informações experimentais da literatura e estruturas da proteína CD38, demonstrou a importância dessas regiões na formação de dímeros e tetrâmeros compatíveis com a associação na membrana e energeticamente possíveis.

- As estruturas tetraméricas formadas pelo docking direcionado formam um bolsão entre os dímeros, tal região poderia ser importante para o influxo do produto catalítico da proteína CD38, o qual foi proposto na literatura por meio de dados experimentais.

- São necessários mais estudos, tanto experimentais quanto in silico, que analisem a formação de tetrâmeros e sua estrutura tridimensional com a proteína CD38 em sua forma completa, além de experimentos que busquem identificar, como por meio de anticorpos conformacionais, os dímeros e tetrâmeros da proteína CD38. 


\section{REFERÊNCIAS}

ADAMS, J.; NASSIRI, M. Acute Promyelocytic Leukemia: A Review and Discussion of Variant Translocations. Archives of Pathology \& Laboratory Medicine, v. 139, n. 10, p. 13081313, out. 2015.

ALESSIO, M. et al. CD38 molecule: structural and biochemical analysis on human T lymphocytes, thymocytes, and plasma cells. Journal of immunology (Baltimore, Md. : 1950), v. 145, n. 3, p. 878-84, 1 ago. 1990.

ARHUS, R. et al. ADP-ribosyl cyclase and CD38 catalyze the synthesis of a calciummobilizing metabolite from NADP. The Journal of biological chemistry, v. 270, n. 51, p. 30327-33, 22 dez. 1995.

About HCDM. Disponível em: <http://www.hcdm.org/index.php/about-hcdm>. Acesso em: 18 jul. 2017.

BERMAN, H. M. et al. The Protein Data Bank. Nucleic acids research, v. 28, n. 1, p. 235-42, 1 jan. 2000.

BHAN, A. K. et al. Location of T cell and major histocompatibility complex antigens in the human thymus. The Journal of experimental medicine, v. 152, n. 4, p. 771-82, 1 out. 1980.

BRUZZONE, S. et al. Dimeric and tetrameric forms of catalytically active transmembrane CD38 in transfected HeLa cells. FEBS letters, v. 433, n. 3, p. 275-8, 21 ago. 1998.

CHAKRAVARTY, D. et al. Reassessing buried surface areas in protein-protein complexes. Protein Science, v. 22, n. 10, p. 1453-1457, out. 2013.

CHEN, R.; WENG, Z. Docking unbound proteins using shape complementarity, desolvation, and electrostatics. Proteins, v. 47, n. 3, p. 281-94, 15 maio 2002.

CHINI, E. N. et al. Cyclic ADP-ribose metabolism in rat kidney: high capacity for synthesis in glomeruli. Kidney international, v. 51, n. 5, p. 1500-6, maio 1997.

CHIORAZZI, N.; FERRARINI, M. Cellular origin(s) of chronic lymphocytic leukemia: cautionary notes and additional considerations and possibilities. Blood, v. 117, n. 6, p. 17811791, 10 fev. 2011.

CHUANG, G.-Y. et al. DARS (Decoys As the Reference State) Potentials for Protein-Protein Docking. Biophysical Journal, v. 95, n. 9, p. 4217-4227, 1 nov. 2008.

COLAIANNI, G. et al. Regulated production of the pituitary hormone oxytocin from murine and human osteoblasts. Biochemical and Biophysical Research Communications, v. 411, n. 3, p. 512-515, 5 ago. 2011.

DEAGLIO, S. et al. CD38 is a signaling molecule in B-cell chronic lymphocytic leukemia cells. Blood, v. 102, n. 6, p. 2146-55, 15 set. 2003. 
DEAGLIO, S. et al. CD38/CD19: a lipid raft-dependent signaling complex in human B cells. Blood, v. 109, n. 12, p. 5390-8, 15 jun. 2007.

DEAGLIO, S. et al. CD38/CD31, a receptor/ligand system ruling adhesion and signaling in human leukocytes. Chemical immunology, v. 75, p. 99-120, 2000.

DEAGLIO, S. et al. Human CD38 (ADP-ribosyl cyclase) is a counter-receptor of CD31, an Ig superfamily member. Journal of immunology (Baltimore, Md. : 1950), v. 160, n. 1, p. 395402, 1 jan. 1998.

DEAGLIO, S. et al. Human CD38 ligand. A 120-KDA protein predominantly expressed on endothelial cells. Journal of immunology (Baltimore, Md. : 1950), v. 156, n. 2, p. 727-34, 15 jan. 1996.

DIANZANI, U.; MALAVASI, F. Lymphocyte adhesion to endothelium. Critical reviews in immunology, v. 15, n. 2, p. 167-200, 1995.

EGEA, P. F. et al. Insights into the Mechanism of Bovine CD38/NAD+Glycohydrolase from the X-Ray Structures of Its Michaelis Complex and Covalently-Trapped Intermediates. PLoS ONE, v. 7, n. 4, p. e34918, 18 abr. 2012.

FERNÀNDEZ, J. E. et al. Analysis of the distribution of human CD38 and of its ligand CD31 in normal tissues. Journal of biological regulators and homeostatic agents, v. 12, n. 3, p. 8191, [s.d.].

FERRERO, E.; SACCUCCI, F.; MALAVASI, F. The making of a leukocyte receptor: origin, genes and regulation of human CD38 and related molecules. Chemical immunology, v. 75, p. 1-19, 2000.

FRANCO, L. et al. The transmembrane glycoprotein CD38 is a catalytically active transporter responsible for generation and influx of the second messenger cyclic ADP-ribose across membranes. FASEB journal : official publication of the Federation of American Societies for Experimental Biology, v. 12, n. 14, p. 1507-20, nov. 1998.

FRASCA, L. et al. CD38 orchestrates migration, survival, and Th1 immune response of human mature dendritic cells. Blood, v. 107, n. 6, p. 2392-2399, 15 mar. 2006.

GABB, H. A.; JACKSON, R. M.; STERNBERG, M. J. E. Modelling protein docking using shape complementarity, electrostatics and biochemical information 1 1Edited by J. Thornton. Journal of Molecular Biology, v. 272, n. 1, p. 106-120, 12 set. 1997.

GAO, Y.; CAMACHO, L. H.; MEHTA, K. Retinoic acid-induced CD38 antigen promotes leukemia cells attachment and interferon- $\gamma /$ interleukin-1 $\beta$-dependent apoptosis of endothelial cells: Implications in the etiology of retinoic acid syndrome. Leukemia Research, v. 31, n. 4, p. 455-463, abr. 2007.

GAO, Y.; MEHTA, K. N-linked glycosylation of CD38 is required for its structure stabilization but not for membrane localization. Molecular and Cellular Biochemistry, v. 295, n. 1-2, p. 1-7, 22 jan. 2007. 
GARDINER, E. J.; WILLETT, P.; ARTYMIUK, P. J. Protein docking using a genetic algorithm. Proteins, v. 44, n. 1, p. 44-56, 1 jul. 2001.

GELMAN, L. et al. The lymphocyte surface antigen CD38 acts as a nicotinamide adenine dinucleotide glycohydrolase in human T lymphocytes. European Journal of Immunology, v. 23, n. 12, p. 3361-3364, dez. 1993.

GIORGI, J. V et al. CD8+ lymphocyte activation at human immunodeficiency virus type 1 seroconversion: development of HLA-DR+ CD38- CD8+ cells is associated with subsequent stable CD4+ cell levels. The Multicenter AIDS Cohort Study Group. The Journal of infectious diseases, v. 170, n. 4, p. 775-81, out. 1994.

GIORGI, J. V; DETELS, R. T-cell subset alterations in HIV-infected homosexual men: nIAID Multicenter AIDS cohort study. Clinical immunology and immunopathology, v. 52, n. 1, p. 10-8, jul. 1989.

GUSE, A. H. Cyclic ADP-ribose: a novel Ca2+-mobilising second messenger. Cellular signalling, v. 11, n. 5, p. 309-16, maio 1999.

GUSE, A. H. et al. Regulation of calcium signalling in $\mathrm{T}$ lymphocytes by the second messenger cyclic ADP-ribose. Nature, v. 398, n. 6722, p. 70-73, 4 mar. 1999.

HARA-YOKOYAMA, M. et al. Tetrameric Interaction of the Ectoenzyme CD38 on the Cell Surface Enables Its Catalytic and Raft-Association Activities. Structure, v. 20, n. 9, p. 15851595, 5 set. 2012.

HORENSTEIN, A. L. et al. CD38 binding to human myeloid cells is mediated by mouse and human CD31. The Biochemical journal, v. 330 ( Pt 3), p. 1129-35, 15 mar. 1998.

IQBAL, J.; ZAIDI, M. Extracellular NAD+ metabolism modulates osteoclastogenesis. Biochemical and biophysical research communications, v. 349, n. 2, p. 533-9, 20 out. 2006.

JACKSON, D. G.; BELL, J. I. Isolation of a cDNA encoding the human CD38 (T10) molecule, a cell surface glycoprotein with an unusual discontinuous pattern of expression during lymphocyte differentiation. Journal of immunology (Baltimore, Md. : 1950), v. 144, n. 7, p. 2811-5, 1 abr. 1990.

JACKSON, R. M.; GABB, H. A.; STERNBERG, M. J. E. Rapid refinement of protein interfaces incorporating solvation: application to the docking problem. Journal of Molecular Biology, v. 276, n. 1, p. 265-285, 13 fev. 1998.

JIN, D. et al. CD38 is critical for social behaviour by regulating oxytocin secretion. Nature, v. 446, n. 7131, p. 41-45, 1 mar. 2007.

KATCHALSKI-KATZIR, E. et al. Molecular surface recognition: determination of geometric fit between proteins and their ligands by correlation techniques. Proceedings of the National Academy of Sciences of the United States of America, v. 89, n. 6, p. 2195-9, 15 mar. 1992.

KATO, K.; KAMIYA, Y. Structural views of glycoprotein-fate determination in cells. glycobiology, v. 17, n. 10, p. 1031-44, 1 out. 2007. 
KHOO, K. M.; CHANG, C. F. Characterization and localization of CD38 in the vertebrate eye. Brain research, v. 821, n. 1, p. 17-25, 6 mar. 1999.

KOBATA, A.; AMANO, J. Altered glycosylation of proteins produced by malignant cells, and application for the diagnosis and immunotherapy of tumours. Immunology and Cell Biology, v. 83, n. 4, p. 429-439, ago. 2005.

KOZAKOV, D. et al. PIPER: An FFT-based protein docking program with pairwise potentials. Proteins: Structure, Function, and Bioinformatics, v. 65, n. 2, p. 392-406, 24 ago. 2006.

KOZAKOV, D. et al. The ClusPro web server for protein-protein docking. Nature Protocols, v. 12, n. 2, p. 255-278, 12 jan. 2017.

KRAMER, G. et al. High expression of a CD38-like molecule in normal prostatic epithelium and its differential loss in benign and malignant disease. The Journal of urology, v. 154, n. 5, p. 1636-41, nov. 1995.

KRAUSE, D. S.; SCADDEN, D. T.; PREFFER, F. I. The hematopoietic stem cell niche-home for friend and foe? Cytometry. Part B, Clinical cytometry, v. 84, n. 1, p. 7-20, 2013.

KRIEGSMANN, K. et al. Quantification of number of CD38 sites on bone marrow plasma cells in patients with light chain amyloidosis and smoldering multiple myeloma. Cytometry Part B: Clinical Cytometry, v. 94, n. 5, p. 611-620, set. 2018.

KUEMMERLE, J. F.; MAKHLOUF, G. M. Agonist-stimulated cyclic ADP ribose. Endogenous modulator of $\mathrm{Ca}(2+)$-induced $\mathrm{Ca} 2+$ release in intestinal longitudinal muscle. The Journal of biological chemistry, v. 270, n. 43, p. 25488-94, 27 out. 1995.

KUMAR, S. K. et al. Multiple myeloma. Nature Reviews Disease Primers, v. 3, p. 17046, 20 jul. 2017.

LASKOWSKI, R. A. et al. PDBsum: Structural summaries of PDB entries. Protein Science, v. 27, n. 1, p. 129-134, jan. 2018.

LENSINK, M. F.; VELANKAR, S.; WODAK, S. J. Modeling protein-protein and proteinpeptide complexes: CAPRI 6th edition. Proteins: Structure, Function, and Bioinformatics, v. 85, n. 3, p. 359-377, mar. 2017.

LIU, Q. et al. Crystal Structure of Human CD38 Extracellular Domain. Structure, v. 13, n. 9, p. 1331-1339, set. 2005.

MALAVASI, F. et al. CD38 and chronic lymphocytic leukemia: a decade later. Blood, v. 118, n. 13, p. 3470-3478, 29 set. 2011.

MALAVASI, F. et al. Evolution and Function of the ADP Ribosyl Cyclase/CD38 Gene Family in Physiology and Pathology. Physiological Reviews, v. 88, n. 3, p. 841-886, 1 jul. 2008.

MANDELL, J. G. et al. Protein docking using continuum electrostatics and geometric fit. 
Protein engineering, v. 14, n. 2, p. 105-13, fev. 2001.

MEHTA, K.; SHAHID, U.; MALAVASI, F. Human CD38, a cell-surface protein with multiple functions. FASEB journal : official publication of the Federation of American Societies for Experimental Biology, v. 10, n. 12, p. 1408-17, out. 1996.

MENG, X.-Y. et al. Molecular docking: a powerful approach for structure-based drug discovery. Current computer-aided drug design, v. 7, n. 2, p. 146-57, jun. 2011.

MIZUGUCHI, M. et al. Neuronal localization of CD38 antigen in the human brain. Brain research, v. 697, n. 1-2, p. 235-40, 30 out. 1995.

MORENO-GARCÍA, M. E. et al. CD38 is expressed as noncovalently associated homodimers on the surface of murine B lymphocytes. European journal of biochemistry, v. 271, n. 5, p. 1025-34, mar. 2004.

MORRA, M. et al. CD38 is functionally dependent on the TCR/CD3 complex in human T cells. FASEB journal : official publication of the Federation of American Societies for Experimental Biology, v. 12, n. 7, p. 581-92, maio 1998.

MUNSHI, C. et al. The homo-dimeric form of ADP-ribosyl cyclase in solution. Biochimica et biophysica acta, v. 1388, n. 2, p. 428-36, 10 nov. 1998.

MÉSZÁROS, L. G.; BAK, J.; CHU, A. Cyclic ADP-ribose as an endogenous regulator of the non-skeletal type ryanodine receptor Ca2+ channel. Nature, v. 364, n. 6432, p. 76-9, 1 jul. 1993.

NAKAGAWARA, K. et al. Assignment of CD38, the gene encoding human leukocyte antigen CD38 (ADP-ribosyl cyclase/cyclic ADP-ribose hydrolase), to chromosome 4p15. Cytogenetics and cell genetics, v. 69, n. 1-2, p. 38-9, 1995.

NATA, K. et al. Human gene encoding CD38 (ADP-ribosyl cyclase/cyclic ADP-ribose hydrolase): organization, nucleotide sequence and alternative splicing. Gene, v. 186, n. 2, p. 285-92, 28 fev. 1997.

NEWMAN, P. J. Switched at birth: a new family for PECAM-1. The Journal of clinical investigation, v. 103, n. 1, p. 5-9, 1 jan. 1999.

PALMA, P. N. et al. BiGGER: a new (soft) docking algorithm for predicting protein interactions. Proteins, v. 39, n. 4, p. 372-84, 1 jun. 2000.

PRASAD, G. S. et al. Crystal structure of Aplysia ADP ribosyl cyclase, a homologue of the bifunctional ectozyme CD38. Nature structural biology, v. 3, n. 11, p. 957-64, nov. 1996.

QUARONA, V. et al. CD38 and CD157: A long journey from activation markers to multifunctional molecules. Cytometry Part B: Clinical Cytometry, v. 84B, n. 4, p. 207-217, jul. 2013.

REINHERZ, E. L. et al. Discrete stages of human intrathymic differentiation: analysis of normal thymocytes and leukemic lymphoblasts of T-cell lineage. Proceedings of the National 
Academy of Sciences of the United States of America, v. 77, n. 3, p. 1588-92, mar. 1980.

RITCHIE, D. W.; KEMP, G. J. Protein docking using spherical polar Fourier correlations. Proteins, v. 39, n. 2, p. 178-94, 1 maio 2000.

SATO, A. et al. Inhibitor peptide SNP-1 binds to a soluble form of BST-1/CD157 at a 2:2 stoichiometry. European journal of biochemistry, v. 264, n. 2, p. 439-45, set. 1999.

SAVARINO, A. et al. Role of CD38 in HIV-1 infection: an epiphenomenon of T-cell activation or an active player in virus/host interactions? AIDS (London, England), v. 14, n. 9, p. 1079-89, 16 jun. 2000.

SHI, W. et al. Crystal structure of human CD38: Cyclic-ADP-ribosyl synthetase/NAD+ glycohydrolase. TO BE PUBLISHED, [s.d.].

SMYTH, L. M. et al. Novel localization of CD38 in perivascular sympathetic nerve terminals. Neuroscience, v. 139, n. 4, p. 1467-77, jan. 2006.

STATES, D. J.; WALSETH, T. F.; LEE, H. C. Similarities in amino acid sequences of Aplysia ADP-ribosyl cyclase and human lymphocyte antigen CD38. Trends in biochemical sciences, v. 17, n. 12, p. 495, dez. 1992.

TAKASAWA, S. et al. Cyclic ADP-ribose in insulin secretion from pancreatic $\beta$ cells. Science (New York, N.Y.), v. 259, n. 5093, p. 370-3, 15 jan. 1993a.

TAKASAWA, S. et al. Synthesis and hydrolysis of cyclic ADP-ribose by human leukocyte antigen CD38 and inhibition of the hydrolysis by ATP. The Journal of biological chemistry, $\mathrm{v}$. 268, n. 35, p. 26052-4, 15 dez. 1993b.

TERHORST, C. et al. Biochemical studies of the human thymocyte cell-surface antigens T6, T9 and T10. Cell, v. 23, n. 3, p. 771-80, mar. 1981.

TORCHALA, M. et al. SwarmDock: a server for flexible protein-protein docking. Bioinformatics, v. 29, n. 6, p. 807-809, 15 mar. 2013.

VAISITTI, T. et al. CD38 increases CXCL12-mediated signals and homing of chronic lymphocytic leukemia cells. Leukemia, v. 24, n. 5, p. 958-69, 11 maio 2010.

VAN ZUNDERT, G. C. P. et al. The HADDOCK2.2 Web Server: User-Friendly Integrative Modeling of Biomolecular Complexes. Journal of molecular biology, v. 428, n. 4, p. 720-725, 22 fev. 2016.

VERDERIO, C. et al. Evidence of a role for cyclic ADP-ribose in calcium signalling and neurotransmitter release in cultured astrocytes. Journal of neurochemistry, v. 78, n. 3, p. 64657, ago. 2001.

WOLFSON, H. J.; NUSSINOV, R. Geometrical Docking Algorithms A Practical Approach. In: Protein Structure Prediction. New Jersey: Humana Press, 2000. v. 143p. 377-397. 
YAMAMOTO-KATAYAMA, S. et al. Crystallographic studies on human BST-1/CD157 with ADP-ribosyl cyclase and NAD glycohydrolase activities. Journal of Molecular Biology, v. 316, n. 3, p. 711-723, 22 fev. 2002.

ZOCCHI, E. et al. A single protein immunologically identified as CD38 displays NAD+ glycohydrolase, ADP-ribosyl cyclase and cyclic ADP-ribose hydrolase activities at the outer surface of human erythrocytes. Biochemical and biophysical research communications, v. 196, n. 3, p. 1459-65, 15 nov. 1993.

ZOLA, H.; SWART, B. The human leucocyte differentiation antigens (HLDA) workshops: the evolving role of antibodies in research, diagnosis and therapy. Cell Research, v. 15, n. 9, p. 691-694, set. 2005.

ZUCCHETTO, A. et al. CD38/CD31, the CCL3 and CCL4 Chemokines, and CD49d/Vascular Cell Adhesion Molecule-1 Are Interchained by Sequential Events Sustaining Chronic Lymphocytic Leukemia Cell Survival. Cancer Research, v. 69, n. 9, p. 4001-4009, 1 maio 2009. 